Reihe Politikwissenschaft Political Science Series

\title{
European Integration and the Legal System
}

Alec Stone Sweet 

Reihe Politikwissenschaft Political Science Series

\section{European Integration and the Legal System}

Alec Stone Sweet

February 2005

Institut für Höhere Studien (IHS), Wien

Institute for Advanced Studies, Vienna 


\section{Contact:}

Alec Stone Sweet

푤: +44/1865/278599

email: alec.sweet@nuffield.oxford.ac.uk

Founded in 1963 by two prominent Austrians living in exile - the sociologist Paul F. Lazarsfeld and the economist Oskar Morgenstern - with the financial support from the Ford Foundation, the Austrian Federal Ministry of Education, and the City of Vienna, the Institute for Advanced Studies (IHS) is the first institution for postgraduate education and research in economics and the social sciences in Austria. The Political Science Series presents research done at the Department of Political Science and aims to share "work in progress" before formal publication. It includes papers by the Department's teaching and research staff, visiting professors, graduate students, visiting fellows, and invited participants in seminars, workshops, and conferences. As usual, authors bear full responsibility for the content of their contributions.

Das Institut für Höhere Studien (IHS) wurde im Jahr 1963 von zwei prominenten Exilösterreichern dem Soziologen Paul F. Lazarsfeld und dem Ökonomen Oskar Morgenstern - mit Hilfe der FordStiftung, des Österreichischen Bundesministeriums für Unterricht und der Stadt Wien gegründet und ist somit die erste nachuniversitäre Lehr- und Forschungsstätte für die Sozial- und Wirtschaftswissenschaften in Österreich. Die Reihe Politikwissenschaft bietet Einblick in die Forschungsarbeit der Abteilung für Politikwissenschaft und verfolgt das Ziel, abteilungsinterne Diskussionsbeiträge einer breiteren fachinternen Öffentlichkeit zugänglich zu machen. Die inhaltliche Verantwortung für die veröffentlichten Beiträge liegt bei den Autoren und Autorinnen. Gastbeiträge werden als solche gekennzeichnet. 


\section{Abstract}

In this paper, I chart the evolution of the European Community, combining three different perspectives. First, I examine the major features of the integration process since 1959. The evidence shows that European market and polity developed symbiotically, as the activities of economic actors, organized interests, litigators and judges, and the EC's legislative and regulatory organs became linked, creating a self-sustaining, dynamic system. Second, I provide an overview of the 'constitutionalization' of the treaty system, and survey the activities of the European Court. Among other things, constitutionalization secured property rights for transnational market actors, expanded the discretionary powers of national judges, and reduced the EC's intergovernmental character. Third, I examine in detail the impact of the adjudicating the Rome Treaty's free movement of goods provisions (Art. 28-30) on the market building and political integration.

\section{Zusammenfassung}

In dieser Arbeit zeige ich die Entwicklung der Europäischen Gemeinschaft auf, indem drei verschiedene Perspektiven miteinander verbunden werden. Zuerst behandle ich die wichtigsten Eigenschaften des Integrationsprozesses seit 1959. Die Resultate zeigen, dass sich der europäische Wirtschaftsraum und der europäische verfassungspolitische Rahmen symbiotisch entwickelten. Die Aktivitäten der ökonomischen Akteure, der organisierten Interessen, der Kläger und Richter, sowie der europäischen legislativen und regulierenden Organe haben sich verflechtet, was zur Schaffung eines sich selbstversorgenden und dynamischen Systems führte. Zweitens biete ich einen Überblick über die ,Konstitutionalisierung' des Vertragsystems und erhebe die Aktivitäten des Europäischen Gerichtshofes. Unter anderem hat die Konstitutionalisierung die Eigentumsrechte für transnationale Wirtschaftsakteure gesichert, die ,Ermessensmacht' der nationalen Richter ausgeweitet und den intergouvernementalen Charakter der EG geschmälert. Drittens untersuche ich im Detail den Einfluss, den das durch Gerichte anerkannte Prinzip des freien Warenverkehrs, festgeschrieben in den Römischen Verträgen (Art. 28-30), auf die wirtschaftliche Entwicklung und die politische Integration hatte.

\section{Keywords}

Constitutionalization, Supranational Governance, European Court of Justice, Free Movement of Goods 


\section{Schlagwörter}

Konstitutionalisierung, Supernationale Governance, Europäischer Gerichtshof, Freier Warenverkehr

The opinions expressed in this paper are those of the author and not necessarily those of the IHS Department of Political Science 


\section{Contents}

List of Figures $\quad 1$

List of Tables 2

$\begin{array}{ll}\text { Introduction } & \mathbf{3}\end{array}$

1 European Integration and Supranational Governance 5

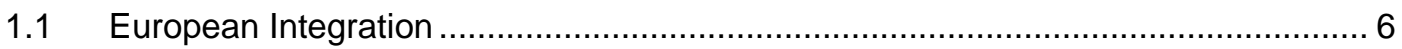

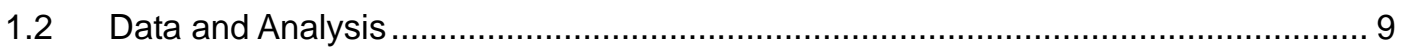

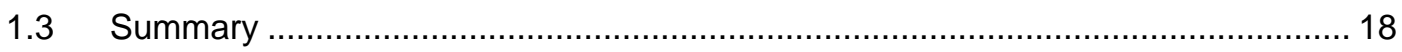

2 Constitutionalization and its Effects 19

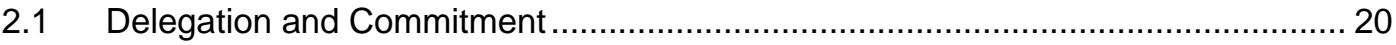

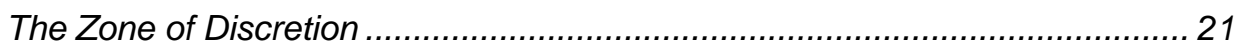

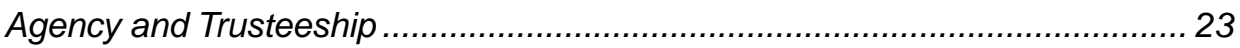

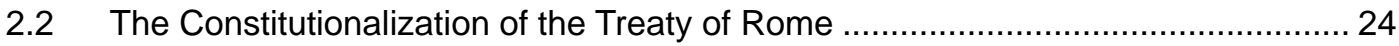

The European Court and the National Courts............................................... 28

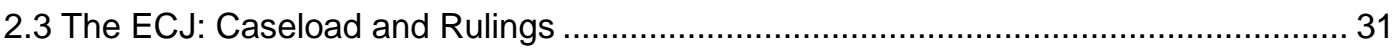

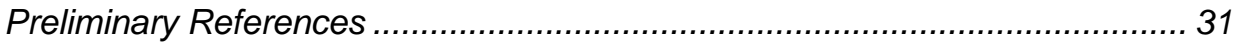

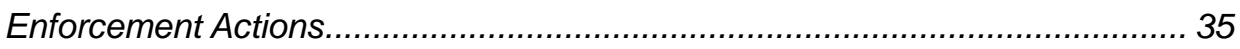

3 The Free Movement of Goods 39

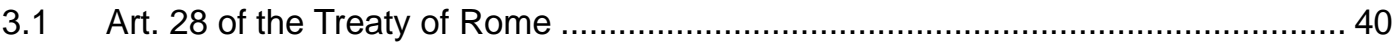

3.2 The Emergence and Consolidation of the 'Dassonville Framework'....................... 41

Dassonville: Hindrance to Trade, Direct or Indirect....................................... 42

De Peijper: Least-Means Proportionality .................................................... 43

Cassis: Mutual Recognition and Strict Scrutiny of Mandatory Requirements ... 46

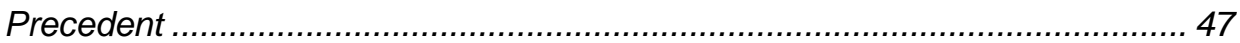

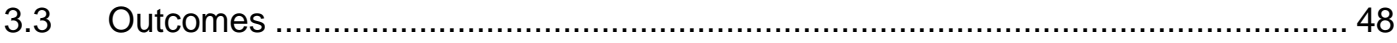

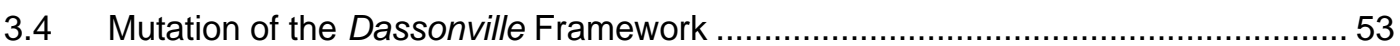

4 Conclusion: Integration, Constitutionalization, Europeanization 54

4.1 The Constitution and Judicial Modes of Governance ......................................... 57

$\begin{array}{ll}\text { References } & 60\end{array}$

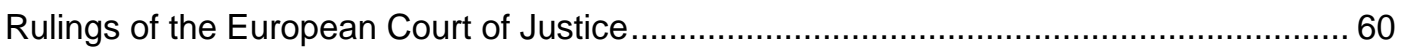

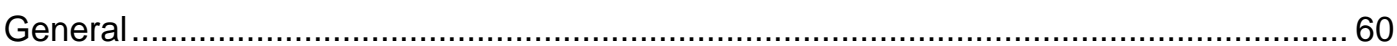





\section{List of Figures}

Figure 1: $\quad$ Annual Levels of Intra-EC Trade, Per Capita .................................................. 11

Figure 2: Annual Levels of Preliminary References and Rulings ................................ 12

Figure 3: Annual Number of Council Directives and Regulations

Adopted

Figure 4: Annual Number of EC Legislative Acts in Force .......................................... 14

Figure 5: $\quad$ Annual Number of EC Lobby Groups Founded............................................. 15

Figure 6: Cumulative Number of Lobby Groups in the EC, Per Year ............................. 16

Figure 7: Annual Number of Preliminary References and Joined

Cases.......

Figure 8: Annual Levels of Infringement Proceedings and Rulings 35

Figure 9: Annual Number of Preliminary References - Free Movement of Goods 


\section{List of Tables}

Table 1: Distribution of Preliminary References by Legal Domain and Period

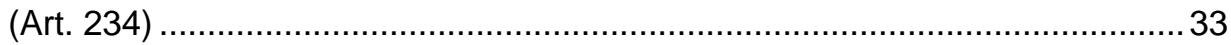

Table 2: Distribution of Infringement Proceedings by Legal Domain and Period (Art. 226)

Table 3: Distribution of Art. 226 Rulings by Legal Domain and Period..... 38 


\section{Introduction}

This paper reports on a research project now completed with the publication of the book, The Judicial Construction of Europe (Stone Sweet, 2004). The project began as a means of testing a theory about how a particular type of social system - a rule of law polity - emerges and evolves, with what political consequences. The theory was developed without reference to the EU. In an initial set of papers, I identified key variables, deduced causal relationships among them, and then used the theory to help explain the judicialization of the GATT-WTO and the French Fifth Republic (Stone Sweet, 1997; 1999). By judicialization, I mean the process through which judicial authority over the institutional evolution of a society is constructed. I then derived a series of hypotheses about how new legal systems would evolve, and began searching for appropriate empirical settings in which to test these propositions.

The European Union (EU) provided an attractive case, as a new, and indeed novel, legal system.1 The system had a clear beginning point; data were, in principle, available; and no systematic social science on how it had developed existed. In 1995, aided by four graduate assistants,2 I began to collect comprehensive data on process associated with integration, including trading, litigating, judging, and legislating in the EC. These data were later supplemented with further information, compiled by Neil Fligstein, on EC lobbying. We then developed a series of tests of our propositions, using both quantitative and qualitative methods; and we considered our findings in the light of current scholarly debates about how to explain the course of European integration (Stone Sweet and Brunell, 1998a; Stone Sweet and Caporaso, 1998). This second set of papers served as the basis for the elaboration and testing of a more general macro theory of integration (Fligstein and Stone Sweet, 2002).3 Finally, in a third part of this research (see also Slaughter, Stone Sweet and Weiler, 1998), we examined interactions between private litigants, national judges, and the European Court, and assessed the impact of these relationships on doctrinal, constitutional, and legislative outcomes (Cichowski, 1998; 2001; Stone Sweet and Brunell, 1998b; 2001; Stone Sweet, 2000). The book "Judicial Construction of Europe" extends and ends the project.

In this paper, I chart the evolution of the European Community, combining three different perspectives. First, I examine the major features of the integration process since 1959. The evidence shows that European market and polity developed symbiotically, as the activities of economic actors, organized interests, litigators and judges, and the EC's legislative and

1 This paper focuses exclusively on the European Community, the first pillar of the EU.

2 Thomas Brunell, now Professor of Political Science at the University of Dallas; Rachel Cichowski, now Professor of Political Science at the University of Washington; Margaret McCown, now a Program Director at the War College; and Markus Gehring, a doctoral student at the Yale Law School.

3 See also Sandholtz and Stone Sweet, 1998; Stone Sweet and Sandholtz, 1999; Stone Sweet, Sandholtz and Fligstein, 2001 
regulatory organs became linked, creating a self-sustaining, dynamic system. Second, I provide an overview of the 'constitutionalization' of the treaty system, and survey the activities of the European Court. Among other things, constitutionalization secured property rights for transnational market actors, expanded the discretionary powers of national judges, and reduced the EC's intergovernmental character. Third, I examine in detail the impact of the adjudicating the Rome Treaty's free movement of goods provisions (Art. 28-30) on the market building and political integration. 


\section{European Integration and Supranational Govern- ance}

The theory of European integration that underlies my research project was built from materials developed in North (1990), recent economic sociology (Fligstein, 2001), and a general theory of judicialized governance (Stone Sweet, 1999; Shapiro and Stone Sweet, 2002). Stripped to bare essentials, the theory focuses on specific causal relationships between three factors, or variables: (a) dyadic contracting, or social exchange, (b) triadic dispute resolution, or 'governance' - defined as the capacity of political organizations to regulate such exchange; and (c) normative structure, including law. Under certain conditions, these three factors will tend to evolve interdependently and, in so doing, constitute and reconstitute a polity (Stone Sweet, 1999). In the context of the EC, these variables are operationalized in ways that highlight their supranational character. Thus, the variable, 'social exchange', includes both economic activity across borders and the growth of transnational civil society. The 'governance' variable includes the evolution of the capacities of the EC's legislative and judicial bodies to authoritatively manage what is, in effect, supranational 'space' (Stone Sweet, Fligstein and Sandholtz, 2001). And the variable, 'normative structure', includes the increased density and articulation in the rule system produced by the EC lawmaking organs and the Court.

There exists a huge body of sophisticated research on European integration that relates to the various themes of this paper. It is important, therefore, to be clear about the nature of the argument and methods, and the scope of the findings. First, compared with virtually any other contemporary approach to integration, the theory is pitched at a higher level of abstraction, and the data analyzed are more comprehensive and more highly aggregated. Our approach is both macro and dynamic, directing attention to how large processes interact, across multiple dimensions, over time. Our goal is to be able to 'see', and make sense of, the main features and patterns exhibited by the integration process, as it proceeds. The theory is relevant to, but cannot on itself explain, many discrete economic, legislative, or judicial events or decisions, at least without being supplemented by detailed case studies. For this reason, the paper examines the doctrinal underpinnings of constitutionalization in detail. These points accepted, I do not ignore relevant scholarship, but rather incorporate the main streams of research on European integration within our more macro theory.

Second, the paper takes on one of the more intractable puzzles of the social sciences: how to account for institutional change in political systems. Even within an increasingly generic 'institutionalist' social science (see Hall and Taylor, 1996), there are important disagreements about whether one should focus primarily on actors (the micro level), organizations (the meso level), or on rule systems (institutions and culture, the macro level). In my view, privileging one level of analysis over another can be justified by the nature of the inquiry, for ex- 
ample, with respect to a specific mechanism of change being explicated or assessed. However, any satisfactory explanation of institutional change must pay close attention to all three levels, as they interact with one another over time.

Third, because at this point I am primarily interested in the relationship between market and political integration in Europe, the issue of how to evaluate the efficiency of rules and governance structures in promoting social exchange is necessarily raised. Organizational economists (e.g. Fama and Jensen, 1983; Williamson, 1985) and most rational-choice political scientists (e.g. Bates et al., 1998) assume that viable, relatively stable institutions are presumptively (usually Pareto) efficient, although efficiency is rarely demonstrated empirically. Economic sociology and students of political culture (e.g. Eckstein, 1988) tend to be agnostic on this same question, or seek to evaluate the functionality of institutions in other than economistic ways, such as with respect to how, and to what extent, they enable human communities to reproduce themselves over time, given changing circumstances. I do not rely on an assumption that EC institutions are optimal, in the sense of being at least as economically 'efficient' as all other possible institutional arrangements. Supranational governance has organized the steady expansion of intra-EC trade and the development of transnational society, primarily by making, interpreting, and enforcing Community law. In the absence of such governance, or in situations in which rule-innovation in the EC has been stalled, transnational exchange would have been stifled, or would have expanded more slowly. For our purposes, it is enough that new EC institutions are functional for market actors in that they are at least relatively efficient compared to preexisting arrangements.

Fourth, our main finding is that, over time, the activities of the EC's organizations mixed with the activities of traders and other transnational actors to produce a self-reinforcing system whereby evolving rule structures and market integration became linked. Our results provide broad support for some of the core claims of 'neofunctionalist' theory, first developed by Ernst Haas (1958; 1961). Haas, not unlike North (1990), tried to show that market expansion and political development could be connected to one another through positive feedback loops that would push steadily for more of both. We formalized these insights as hypotheses, gathered data on the processes commonly associated with European integration, and tested out hypotheses in diverse ways. The evidence supports Haas' basic intuitions.

The next section - based on Fligstein and Stone Sweet (2002) and Stone Sweet and Brunell (1998a) - summarizes our theory and empirical findings. For space reasons, I have chosen not to reproduce the complete statistical analyses here.

\subsection{European Integration}

Integration has been driven by the ways in which specific, otherwise relatively autonomous, fields of action gradually came to be connected to one another. I emphasize three such 
fields: between firms engaged in cross border trade (seeking to open and expand markets); between litigants (seeking to vindicate or develop rights under EC law), national judges (seeking to resolve disputes to which EC law is material), and the European Court; and between lobbying groups (seeking to exercise influence on EC regulation that affects them) and the EC's legislative bodies (seeking to maximize their control over policy outcomes). I assume that the Commission and the Court primarily work to extend the scope of supranational governance over market activities, and to enhance the effectiveness of EC law within national legal systems. I assume that national governments pursue their own interests, which are at least partly determined by their calculations on how best to win the next election and remain in power; but we also expect the activities of governments, as they relate to the EC, to be conditioned by the constraints of growing economic interdependence, and by EC rules and procedures as they evolve over time.

We begin by taking up four different, but well-known, stories that scholars have told about market and polity building under the Treaty of Rome.

The first focuses attention on the consequences of rising economic transactions across borders. The flow of goods, services, investment, and labor across national boundaries not only generated economic growth that states came to rely upon, but created or accentuated a host of transnational governance problems (the negative externalities of economic interdependence). Those who transacted across borders actively pressured governments and the EC's organizations to remove national barriers to further economic exchange (negative integration), and to regulate, in the form of European legislation (positive integration), the emerging Common Market (Mattli, 1999; Moravscik, 1993; 1998; Stone Sweet and Brunell, 1998a; Scharpf, 1996). Certain groups, like large export-oriented firms, have benefited more from market integration than have smaller non-exporting firms (Fligstein and Brantley, 1995); and some believe that integration has contributed to the erosion of national systems of social welfare and interest representation (e.g. Schmitter and Streek, 1991).

The second narrative traces the causes and effects of the 'constitutionalization' of the Treaty of Rome (Burley and Mattli, 1993; Shapiro, 1992; Stein, 1981; Weiler, 1990; 1999): the mutation of the $\mathrm{EC}$ from an international regime to a quasi-federal polity through the consolidation of the doctrines of direct effect and supremacy. Among other things, the doctrine of direct effect enables private actors to plead rights found in EC law against public authorities in national courts, and the doctrine of supremacy requires national judges to resolve conflicts between EC and national law with reference - and deference - to the former. Two basic dynamics were quickly established (Stone Sweet and Caporaso, 1998). First, transnational economic actors litigated to remove national hindrances to their activities; and, second, individuals and groups not directly engaged in cross-border exchange - such as those who seek to enhance women's rights - sought to use the EC legal system to destabilize or reform national rules and practices. In many legal domains, including those governing the free movement of goods and of workers, social policy and environmental protection, the operation of 
the legal system, has pushed the integration project a great deal further than the Member State governments, operating under existing decision rules, would have been prepared to go on their own (Stone Sweet, 2004).

These outcomes were in no sense preordained. The Member States did not design the legal system that ultimately emerged. Legal elites (lawyers activated by their clients, and judges activated by lawyers) had to figure out how to use European law, to make it work in their interests. A modicum of consistency in the Court's constitutional case law helped, but it also forced national judges to confront complicated problems concerning the nature and enforceability of EC law, standing requirements, and remedies (Ward, 2000). Hardly passive, national judiciaries negotiated their relationship to the European Court of Justice within a set of multidimensional, intra-judicial, "constitutional dialogues" (Slaughter, Stone Sweet and Weiler, 1998). The system, built by judicial lawmaking, evolved through use, not by institutional design.

Our third integration narrative traces the myriad effects of the growth and institutionalization of interest group representation at the supranational level. The Commission is a small organization. Even today, only about 16,000 people work for it, and probably fewer than 2,000 are directly involved in policymaking (Fligstein and McNichol, 1998). Given the potentially huge scope of its jurisdiction and responsibilities, the organization possesses relatively little capacity to generate serious study of complex issues in order to facilitate agreements, and even less capacity to enforce and administer European rules once they are adopted. The Treaty did not design a system of accommodating lobbying organizations in Brussels, nor did it outline procedures for incorporating them into the policy process.

Early on, the Commission worked hard to co-opt technical experts and directly affected parties into the policy process, to help draft new and assess existing market rules, and to help legitimize new proposals proposed. Producer groups, who had the biggest, immediate stake in market integration, dominated lobby activity. As the scope and density of EC rules increased, more and more groups, including those representing 'diffuse', public interests, discovered that it paid to set up shop in Brussels (Mazey and Richardson, 1993; Pollack, 1997). In the 1980s, Brussels became "a lobbyist's town" (Harlow, 1992), as complex symbiotic relationships developed between lobby groups and the Commission. Today, a wide range of policy outcomes can only be understood by taking into account the influence of these groups (Anderson and Eliasson, 1991; Greenwood and Aspinwall, 1998), within increasingly institutionalized procedures for consultation and participation (Dogan, 1997; Joerges and Neyer, 1997; Mazey and Richardson, 2001). 
A fourth stream of scholarship seeks to explain the sources and consequences of permutations in the EC's legislative procedures (Jupille, 2004; Moravcsik, 1998; Tsebelis and Garrett, 2001). As noted, the most important changes have been the move away from unanimity voting and the enhancement of the role of the European Parliament, beginning in the mid1980s. Perhaps controversially, I see intergovernmental bargaining and the evolution of procedures that structure it as being embedded in the overall process of integration (Stone Sweet and Sandholtz, 1997; 1999; 2002).

There are good a priori reasons to think that the activities of market actors, lobbyists, legislators, litigators, and judges were in fact connected to one another, both directly and through feedback loops. For the sake of brevity, I will provide stylized examples of such linkages, without fully developing the theoretical foundations for these expectations (see Fligstein and Stone Sweet, 2002). Thus, given certain necessary causal conditions - the most important of which is the acceptance of supremacy and direct effect by national judges, and the entry into force of free trading rules in 1970 - rising intra-EC trade could be expected to generate litigation, as importers found their activities hampered by national hindrances to trade. A more stringent hypothesis: relatively more trade would produce relatively more litigation, and thus relatively more references to the Court. These hypotheses are testable, both cross-nationally and across time. Further, to the extent that the legal system actually did remove trade obstacles, more cross-national exchange would be stimulated. A feedback loop would thereby be constituted, one that connects intra-EC trade to the litigation of EC law. There were also good reasons to expect that as EC secondary legislation was produced, in more and more domains, an increasing number of lobby groups would choose to set up shop in Brussels; and we expected - the feedback loop again - that lobbyists would help produce more legislation in the arenas in which they operated. A third example: we expected that legislating and litigating could also become connected, since new regulations and directives (if directly effective) give private actors new grounds on which to plead rights under EC law, before national courts. These latter two logics could be formalized as testable hypotheses, not only across time, but across policy domains: new legislation in specific domains of EC law (e.g. agriculture, consumer protection, sex equality, etc.) would stimulate more lobbying and more litigating, which might then generate the attendant feedback effects.

\subsection{Data and Analysis}

We collected data on indicators of our variables, measures of the 'outputs' of the system. For legislating, lobbying, and litigating in the $\mathrm{EC}$, we compiled comprehensive information on activity across the sixteen main policy domains designated by the Commission to be under 
the EC's jurisdiction, for the 1959-98 period. These data allowed us to compare, and to analyze statistically, the extent to which any given policy domain has been the site of each form of activity, relative to other domains, across time. For the indicator of economic interdependence within Europe, we used different measures intra-European trade; unfortunately, comprehensive data on other kinds of economic transactions, such as capital and labor flows since 1959, do not exist. However imperfect, the choice of trading as an indicator of transnational economic activity is defensible given the fact that creating a free trade zone within Europe was the originally core objective of the Rome Treaty.

Figures 1-6 report, as time series, the outputs of each of our four processes. Taken together, these figures depict what any theory of integration must seek to explain. In our analysis of the data, we found that European integration has been sequenced in three main periods. In the first period, roughly 1958-1969, actors were engaged in the process of building the EC's main organizations and figuring out how to make the Treaty of Rome work; and they succeeded in establishing the common agricultural policy and important competition rules. The pivotal institutional innovation during this period was the constitutionalization of the Treaty through the diffusion of the Court's doctrines of supremacy and direct effect. During the second period, roughly 1970-1986, the EC's organizations worked to dismantle barriers to intraEC trade and other kinds of transnational exchange (negative integration). At the same time, the Commission and the Council sought to replace the disparate regulatory regimes in place at the national level with harmonized, EC regulatory frameworks (positive integration). Although the data show that positive integration proceeded more steadily than is often appreciated, many important harmonization projects stalled, not least, because more ambitious initiatives required the unanimous vote of national ministers. The unanimity rule, a product of the Luxembourg compromise, made it very difficult to forge such agreements, at a time when an increasing number of social and economic actors were pressing for wider and deeper integration. This period ended with the passage of the Single European Act 1986, which altered the voting rules for adopting most legislation pertaining to the Single Market Program, from unanimity to Qualified Majority Voting (QMV). Our final period, post-SEA, has been the most active from the perspective of positive integration.

This periodization of the EC's activities can help make sense of the broad patterns of growth in trade, legislation, litigation, and lobbying across the life of the EC. Figure 1 presents the growth in intra-EC trade per capita for the period 1961-98. One observes a slow increase, but relatively low levels of trade during the 1960s. In 1970 as EC rules start to bite, exports rise more steeply. Following 1985 with the announcement of the Single European Act, growth in trade accelerates. Changes in patterns of intra-European trade coincide with important events within the EC. The rules governing free movement of goods, such as the prohibition of maintaining national quotas and other measures of equivalent effect, entered into force on January 1, 1970, and thereby became directly effective for traders. In 1986, the EC agreed to the completion of the Single Market and to important changes in the voting rules just discussed. 
Figure 1: Annual Levels of Intra-EC Trade, Per Capita*

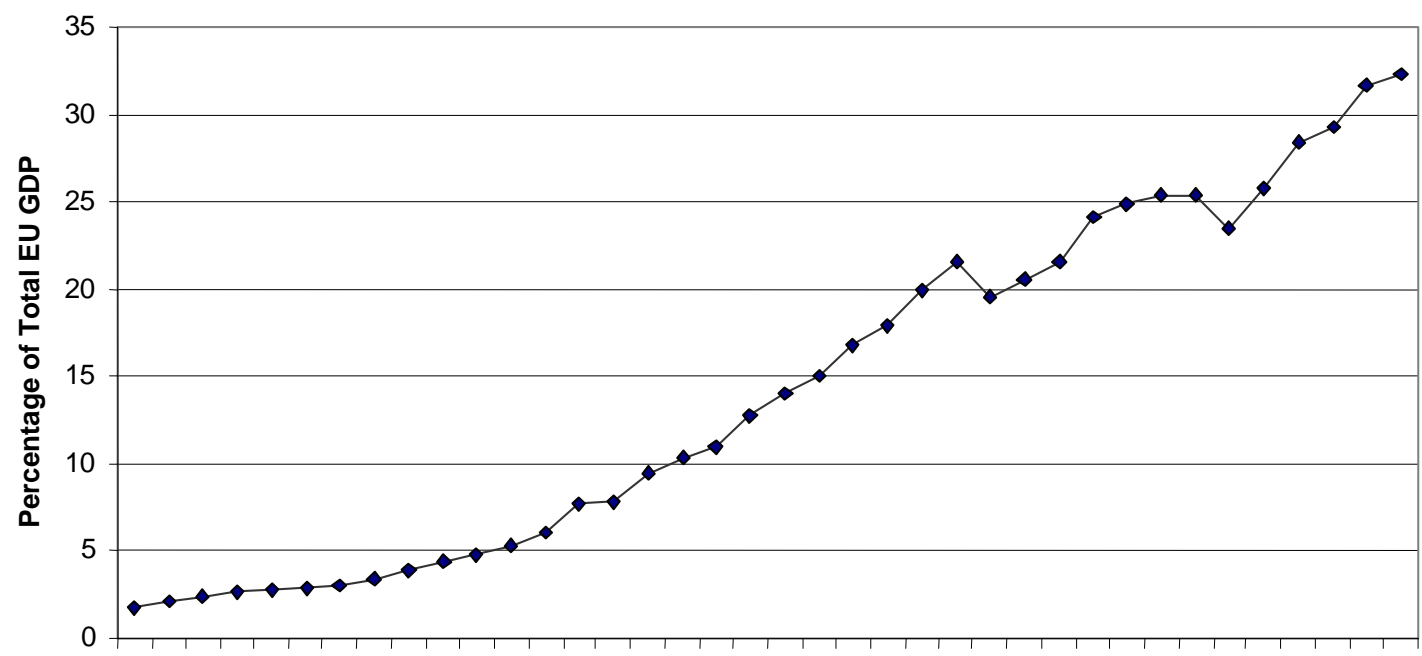

1961196319651967196919711973197519771979198119831985198719891991199319951997

Year

- Annual Intra-EU Trade as a \% of GDP

* Calculated by dividing total amount (2003) of intra-EU trade per year by total population of all EU Member States. Source of the trade data: Pitarkis and Tridmas

Changes in trade are mirrored in changes in litigating and legislating. Figure 2 tracks annual levels of preliminary references and preliminary rulings by the European Court, since the first such reference in 1961. This measure is the best indicator now available of the degree to which EC law is litigated in national courts. It bears emphasis, however, that these numbers represent only the tip of the iceberg, 4 since today most cases that are resolved by national judges involving European law do not lead to a referral. The figure shows that levels of references were very low during the 1960s, and began to pick up after 1970, when common market rules entered into effect, and as the doctrines of supremacy and direct effect gradually diffused throughout the system. References doubled by 1980, leveled off in the mid-1980s, and climbed dramatically after the Single Act.

4 A far better measure of the 'EC litigation' variable would be information concerning cases brought before national judges (over time, and across policy domains and jurisdictions) in which at least one of the parties based pleadings on EC legal norms. These data have never been collected. 
Figure 2: Annual Levels of Preliminary References and Rulings*

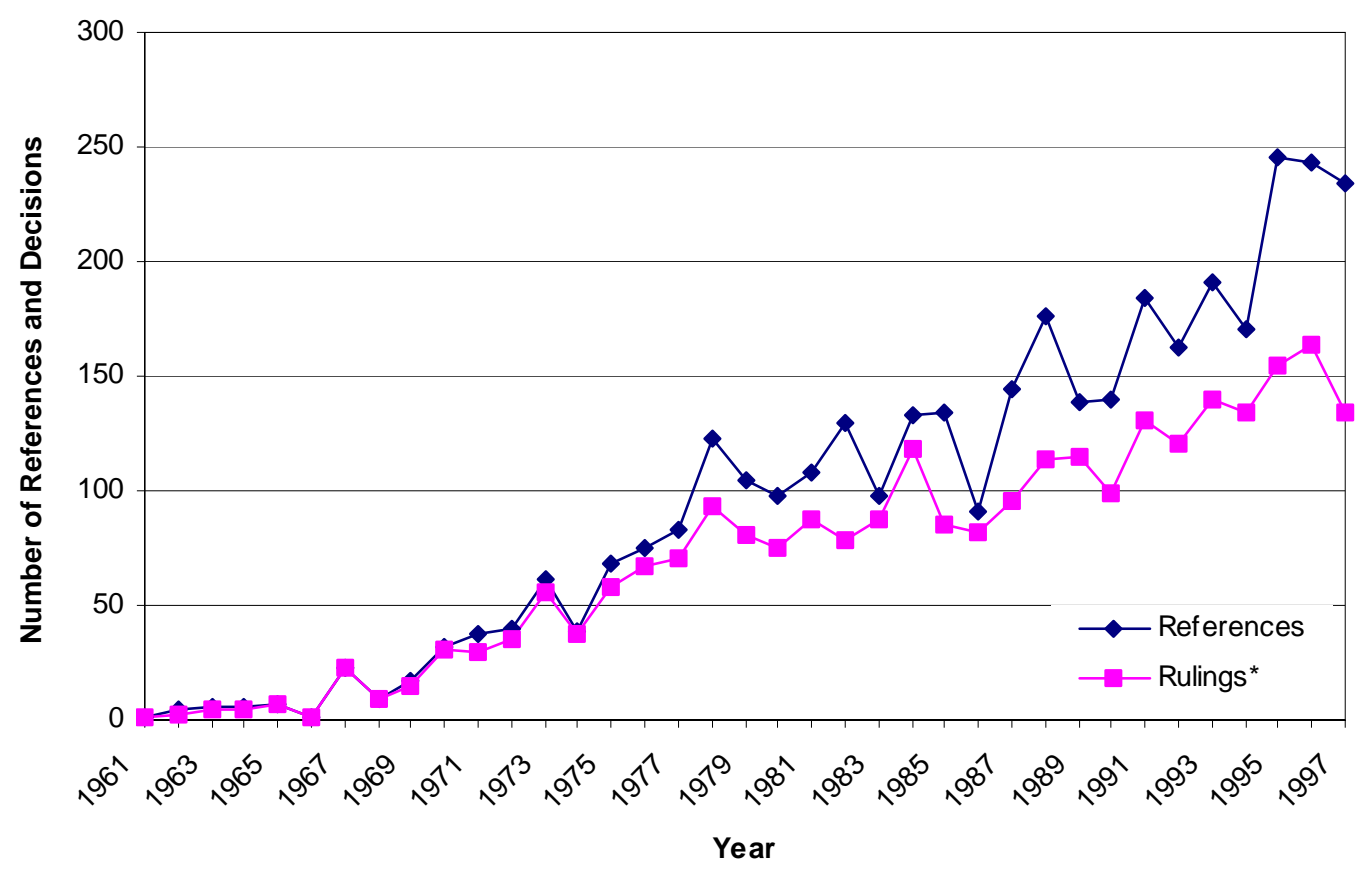

* 'Rulings' includes references ended by a judgment or an order of the Court.

Source: Alec Stone Sweet and Thomas Brunell Data Set on Preliminary References in EC Law, 1956-98, Robert Schuman Centre for Advanced Studies, European University Institute (San Domenico di Fiesole, Italy: 1999). See Stone Sweet and Brunell (2000).

The adoption of EC statutes is a reasonable indicator of positive integration, since much of this activity is oriented towards producing 'harmonized' market rules to replace national regulation. Unfortunately, obtaining reliable data on the EC's lawmaking activities is fraught with difficulty, given inconsistencies in the methods used by reporting services (see Maurer and Wessels, 2003; Page and Dimitrakopoulos, 1997). Figure 3 depicts the number of EC legislative acts in force, measured at annual intervals for the 1983-98 period. The pattern that emerges closely resembles that which appears for trade and litigating. Figure 4 tracks the annual production of secondary legislation - Directives and Regulations - produced by the EC legislator through the complete legislative process. Legislative activity during the 1960s was relatively low, if rising. It picks up during the 1970s, and peaks in 1978. Between 1978 and 1985, the production of statute stabilizes, and then takes off after the passage of the Single Act. The data we collected show that legislative activity actually begins to decline in the 1990s (as do the data compiled by Maurer and Wessels, 2003). What figure 4 does not show is the huge growth in delegated legislation (including so-called 'legislative decisions') that takes place in the 1990s. 
Figure 3: Annual Number of Council Directives and Regulations Adopted

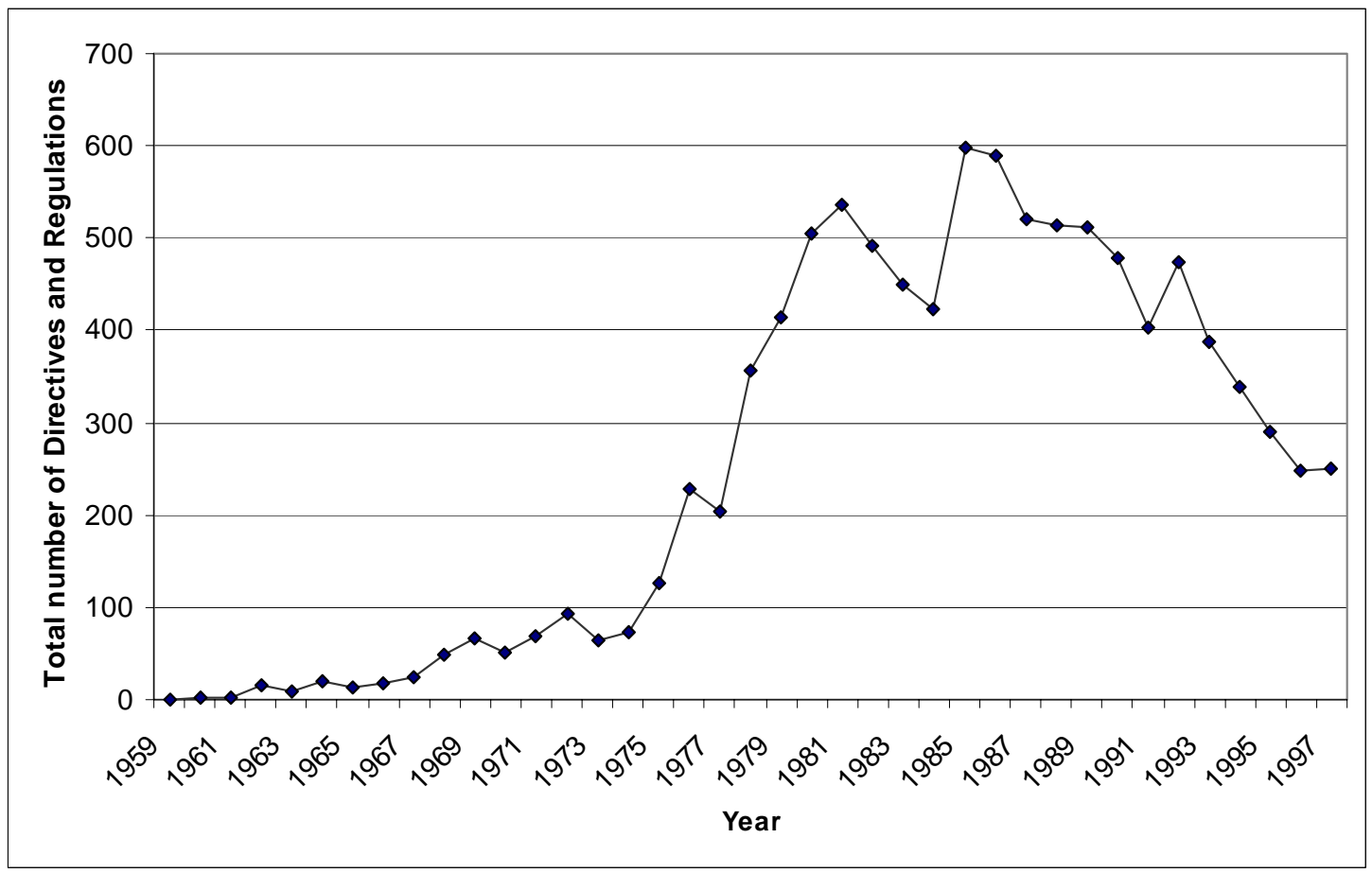

Source: Compiled by Christine Mahoney and Alec Stone Sweet from EU Directory of Legislation in Force (2003). 
Figure 4: Annual Number of EC Legislative Acts in Force

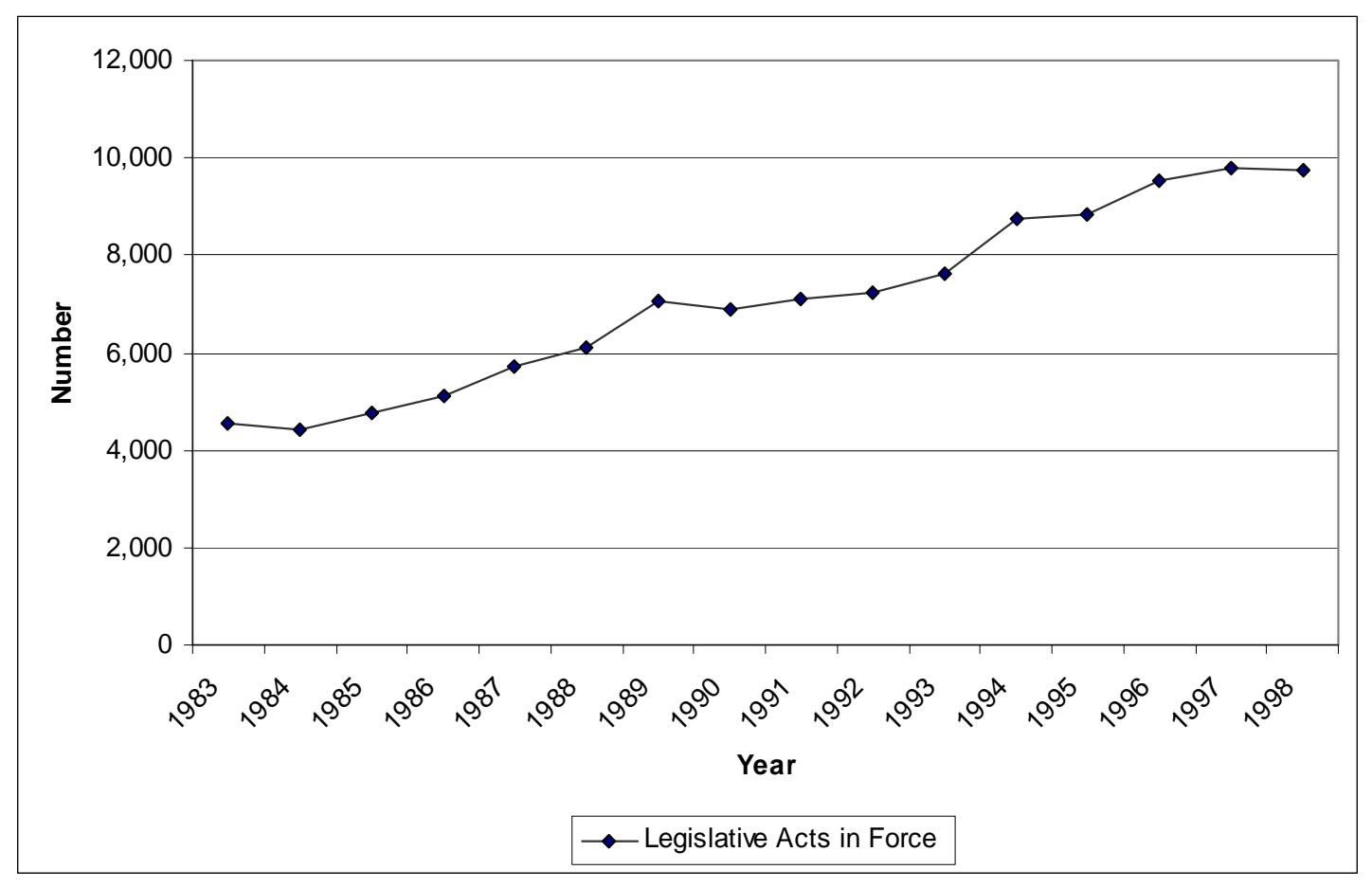

Source: Maurer and Wessels (2003).

Figure 5 presents information on the formation of lobbying groups in Brussels, over time. We were able to compile information on almost 600 significant lobbying groups; our database understates the number of groups at any point in time, and reflects the activities of bigger and more stable groups. The beginning of the EC witnessed a flurry of foundings, which decreased during the mid 1960s, and then bounced around during the 1970s and early 1980s. Following the passage of the Single Act, the establishment of new lobbying groups shot upward. 
Figure 5: Annual Number of EC Lobby Groups Founded

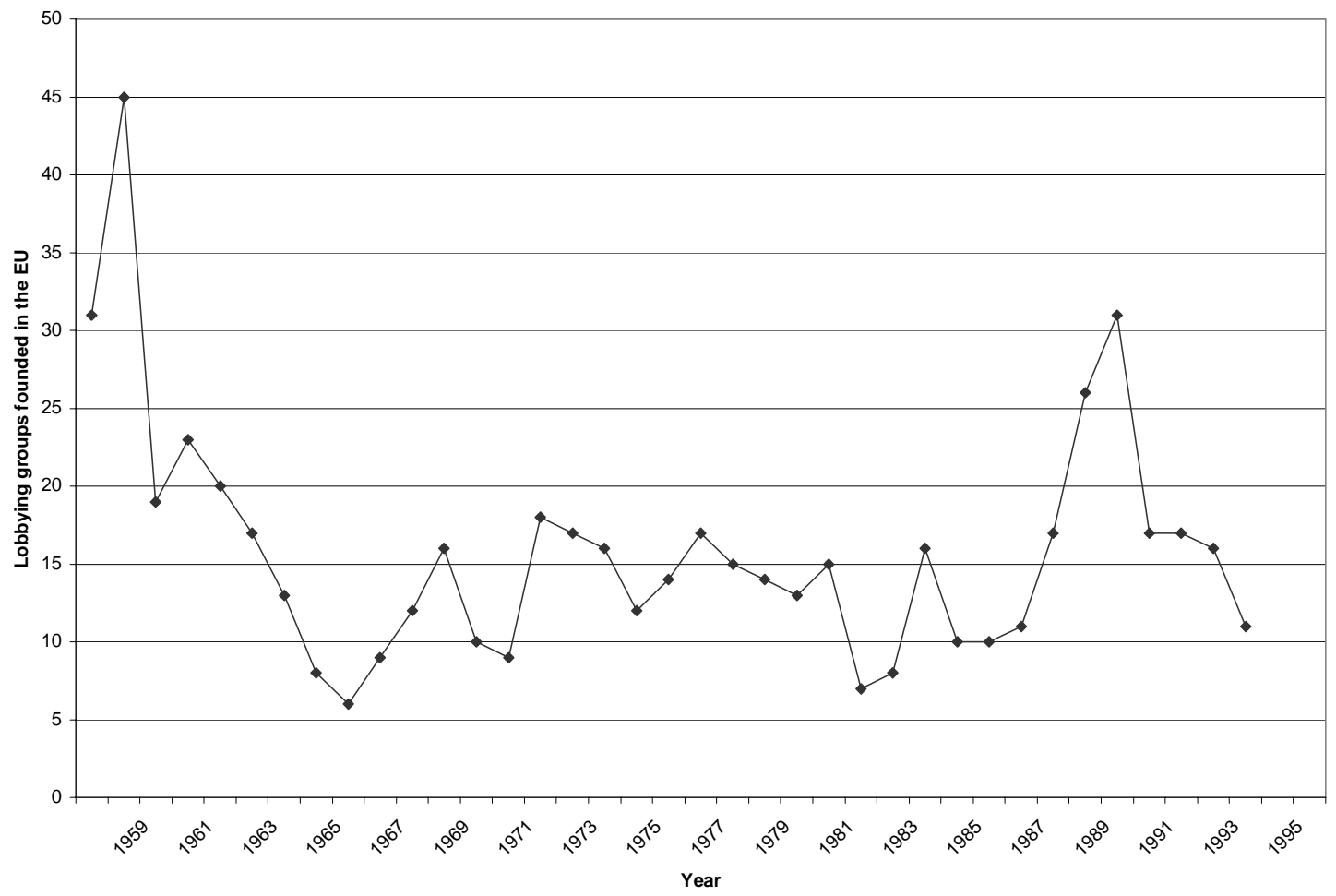

Source: Fligstein and Stone Sweet (2002).

Figure 6 presents data on the cumulative number of lobbying groups in Brussels, over time. Clearly, the Single European Act convinced groups that being in Brussels mattered, and that new legislative initiatives further stimulated the formation of new lobbying groups. 
Figure 6: Cumulative Number of Lobby Groups in the EC, Per Year

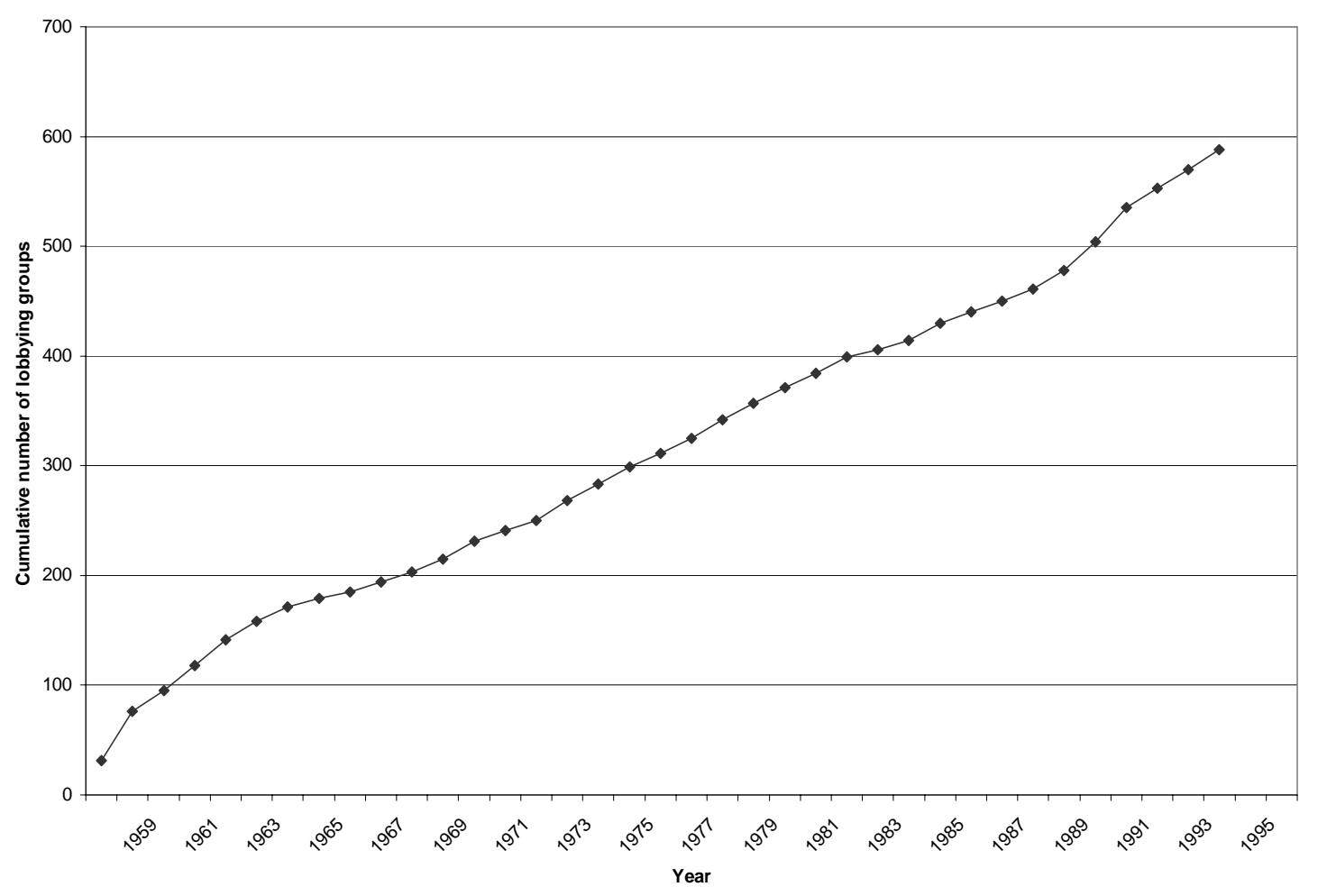

Source: Fligstein and Stone Sweet (2002).

We used these data, and our cross-domain data on legislating, lobbying, and litigating in the $\mathrm{EC}$, to test a series of hypotheses about how integration has proceeded, using econometrics and other statistical methods. Our most important findings can be briefly stated.

First, trading, litigating, legislating, and lobbying - key indicators of European integration and supranational governance - grew over time, along roughly similar paths. Indeed, we found that two large 'parameter shifts' - whereby important qualitative events generated quantitatively significant transformations in how our variables interact - have occurred in the development of the EC: the first around 1970; the second after 1985. The claim is not that in 1970, and again in 1986, everything that matters suddenly changed. On the contrary, each period generated, and passed forward to the next, institutional materials that structured what took place thereafter. To take one pertinent example, the doctrines of supremacy and direct effect, established in the first period, constituted necessary conditions for the expansion of litigation and the subsequent development of the Court's famous doctrine of mutual recognitions during the second period. During the second period, the Commission, in alliance with transna- 
tional business coalitions, built on the Court's work, successfully converting Member State governments to the idea that mutual recognition6 could ground a general strategy for moving market integration forward (Stone Sweet, 2004).

Second, market integration and the construction of the legal system have been mutually reinforcing processes. Intra-EC trade has been the fundamental determinant of litigating EC law in the national courts. The underlying logic of this relationship should be obvious. In the beginning, those who had the most to gain from economic transactions across borders were the most likely benefactors and users of the EC Treaty, and were the most likely to use litigation in the service of negative integration. As important, they possessed the resources to use litigation as a means of evolving EC rules in their favor, and in pro-integrative directions. At the same time, we found that legal integration stimulated intra-EC trade. Blending a modified neo-functionalism with a concern for the transaction-costs of trade, we had proposed that to the extent that the legal system actually removed barriers to transnational exchange, more intra-EC trade would be generated (Stone Sweet and Brunell, 1998a). Both the aggregate quantitative analysis and the qualitative assessment of the adjudication and evolution of the EC's trading institutions, show the causal connections between trading and litigating to be extraordinarily robust.

Following from this analysis, two economists recently subjected the latter hypothesis - the operation of the EC's legal system stimulates intra-EC trade - to a more sophisticated set of statistical tests, using updated measures. Pitarkis and Tridimas conclude that "the establishment of an EU-wide legal order and a system of dispute resolution with the ECJ at the top, leads to deeper economic integration expressed as a larger share of intra-EC trade in economic activity" (2003: 365). Their findings provide solid support for our theory, and for the modified neo-functionalist view.7

Third, we found that EC legislative activity and the litigation of EC law were connected in various ways. Most important for present purposes, the impact of trade on litigating is declin-

6 If it makes sense to analyze some of the broad dynamics in terms of three periods that comprise a single overall process, we also recognize that this process has always been messy and complex. Much of importance will not be captured by schema that aggregate complex phenomena across time and policy space. Nevertheless, the claim is that how our three meta-variables interact - that is, the various relationships between (a) transnational activity like cross-border trade and the activities of supranational interest groups; (b) the litigation of EC law; and (c) the rulemaking capacities and activities of EC organizations - alter meaningfully from one period to the next.

7 Curiously, Pitarkis and Tridimas (2003) state that their analysis does not provide support for neo-functionalist integration theory. Yet we derived their central hypothesis from our theory, explored the same relationship, and predicted their findings (Stone Sweet and Brunell, 1998a). Haas (1961) explicitly states that his theory is principally concerned with how new EC institutions feed back on transnational society to stimulate more cross-border exchange, thereby raising the costs of intergovernmental stalemate. In any case, the theoretical underpinnings of the even more generic proposition - that complex social exchange depends heavily on rules, property rights, and contract enforcement - is central to the approach of this paper, as well as to that of North (1990), Stone Sweet (1999), and Stone Sweet and Fligstein (2002), among others. 
ing over time, while the impact of the EC rule structure is rising. Put differently, the relative importance of negative integration and positive integration has been reweighted in favor of the latter.

Fourth, we found, at the domain level, that the growth in EC legislative activity attracted interest groups to Brussels. Further, it was the higher density of lobbying groups in any given policy domain that helped to produce more legislation, while encouraging new groups to set up shop in Brussels. This is a relatively pure measure of the political success of the EC. As some groups achieved influence over legislation, others perceived the necessity of joining them in Brussels, or suffer being left out of processes that would impact them. The positive integration project was pushed, in part, by this 'bandwagon' effect. There is also evidence that the impact of big export or trading concerns has declined, as more diffuse, public interests have become better organized in Brussels.

Last, trading and legislating in the EC are strongly correlated. Rising economic interdependence has led the EC's legislative organs to produce an extensive, highly differentiated regulatory structure. At the same time, positive integration further reduced the transaction costs of transnational economic activity, through opening markets and harmonizing standards and other market rules. We found no significant causal connections between lobbying and trading, or between lobbying and litigating.

\subsection{Summary}

When one observes the overall sweep of European integration, one sees that transnational economic activity, litigating, legislating, and lobbying did not take place in isolation from, but in fact became connected to, one another. The Treaty of Rome created vast potential for export-oriented European firms to derive benefits associated with larger and more open markets. It created two sets of organizations, one legislative and one judicial, to help governments achieve their goals. Market actors began to take decisions in light of this new institutional structure, and to orient themselves to emerging European spaces; the EC legislative organs began to operate, opening up new sites for political activity; and the EC's legal system was (re)constituted on the basis of the Court's constitutional doctrines, creating an avenue of direct action for private parties. As an ever-widening range of national regulation and administrative practices were placed in the shadow of EC law, and as actors advantaged by EC institutions pushed for more integration through lobbying and litigation, EC legislators found that the search for supranational solutions to the problems posed by the expansion of transnational society and economic interdependence were the only feasible response. And, as the EC's rule structure became more dense and differentiated, so did the grounds for legal action, and actors moved to push the EC to establish or interpret new rules in their favor. 


\section{Constitutionalization and its Effects}

I have argued that the broad expansion of supranational governance in Europe since 1960 is embedded in two other large processes: rising economic interdependence and the growth of transnational society. Despite the difficulties of achieving agreement among the Member States on many key issues, market and political integration proceeded, propelled forward by the expansive dynamics of the causal system just described. Still, that system could not have been forged without a measure of individual property rights, a system of effective adjudication, and a lawgiver. For well-known reasons (Waltz, 1979), these conditions have been notoriously difficult to create and sustain in the inter-state system.

In Europe, the six states that signed the Treaty of Rome were able to overcome some of these difficulties, but only in part. The Treaty contained important restrictions on state sovereignty, such as the prohibition, within the territory constituted by the EC, of tariffs, quantitative restrictions, and national measures 'having equivalent effect' on trade after December 31,1969 . It enabled the 'pooling of state sovereignty', creating legislative institutions and a process for elaborating common European policies. And it established 'supranational' institutions, including the Commission and the ECJ, to help the Council of Ministers - and later the EP - to legislate and resolve disputes about the meaning of EC law. Nonetheless, despite these and other important innovations, the Member States founded an international organization, not a constitutional, or federal, polity. Some Treaty provisions announced principles that, if implemented, would directly impact individuals - including the free movement of workers, and equal pay for equal work between men and women - but the Member States did not mean for the Treaty to confer judicially-enforceable rights on individuals. Further, even within a free trade zone, the transaction costs facing traders would be higher than transaction costs within a single national market, to the extent that traders could not rely on a secure legal framework comparable in its efficacy to that furnished by national legal systems. In contrast to the American constitution, the Rome Treaty neither contains a supremacy clause nor provides for a hierarchically arranged judicial system (i.e. with a supreme court at its apex).

In this section, I consider the impact of the ECJ's moves to reconstruct the legal system on the basis of supremacy, direct effect, and related constitutional doctrines. I begin with a more general theoretical discussion: of delegation and commitment, and of trusteeship and agency. I then summarize the Court's 'constitutional' case law. These judgments reconfigured the normative foundations of the Community, thereby upgrading the capacity of the legal system to respond to the demands of transnational society. It bears repeating that this case law constitutes a necessary condition for European integration to have proceeded in the ways that it has. Our argument is not a purely functional one - that the growth of intra-EC trade inexorably led to the construction of the legal system - or that functional demands for 
new institutions somehow magically produced them. Instead, legal integration has been powerfully conditioned by the causal linkages that developed between transnational economic activity and the litigation of EC law in the courts of the Member States; and these linkages depended critically on the Court's success in having its constitutional vision of the EC accepted by the national courts. Thus, in our account, supremacy and direct effect - which are basic to the emergence of secure property rights for European market actors - come first, causally. I then examine more closely how the legal system has operated, and provide an overview of the ECJ's main activities.

\subsection{Delegation and Commitment}

The logic of pre-commitment, or self-binding, has always lurked behind arguments for constitutional review within federal arrangements. Federations are cartels and, as such, they are unstable. One classic rationale for federalism has been to build larger and more open markets. Let's assume that the members of the cartel have decided to pursue their collective interest to liberalize trade across borders, and that they have done so by adopting rules to govern such trade. The resulting situation is typically modeled as a prisoner's dilemma. Each member can gain advantage, vis à vis other members, if it chooses to ignore the obligation to open markets while others obey it. We have good reason to expect that the outcome will be that no cartel member complies fully with the agreement. One means of stabilizing incentives to cooperate is to build a system capable of effectively monitoring and enforcing the rules governing federalism. Courts provide such a mechanism.

Federal systems sustained through effective constitutional review can be expected to evolve in ways that centralize power. The result hinges in part on the extent to which the court performs its assigned role, and in part on dynamics within the federation itself. If the joint gains of cooperation are important enough, each constituent member of the cartel has an interest in ensuring that every other member obeys the rules of the federation, and thus has an interest in supporting the court, even if some decisions go against it. The logic of long-range reciprocity comes to govern the arrangement, reducing debilitating concerns about short-term relative gains and losses, and legitimizing judicial authority.

More generally, contracting generates a functional demand for judicial discretion, and certain forms of constitutional contracting - the establishment of federalism and rights - imply the need for an effective mechanism of constitutional judicial review. The link between (a) the problems of imperfect commitment and incomplete contracting and (b) the extent of political power, or discretion, delegated to the constitutional judge should be obvious (see also Stone Sweet, 2000). Further, constitutional obligations are typically expressed in quite general, even vague, language, not least because vagueness can facilitate the reaching of agreement in the first place. As Shapiro noted, "the more general the text, the more discretion to the interpretor" (1999: 323). And constitutions are often more difficult to amend than other 
forms of public law, reflecting the fact that the underlying commitment problem is often more acute. Obviously, the harder it is for non-judicial authority to nullify the effects of the court's decision-making, the more likely it will be that judicial authority will exercise decisive influence over the institutional evolution of the polity.

\section{The Zone of Discretion}

In Europe, how has the legal system been able to have such an important impact on the course of integration? One way to respond it to focus on judicial discretion: the authority of judges to interpret and apply legal rules to situations, in order to resolve disputes.

I propose a simple model of judicial discretion and power, built of three elements, or determinants. Each determinant possesses its own independent logic, yet each also conditions how the other two logics operate. Given a steady caseload, these three factors will combine, dynamically, to determine the scope of the power of judges to control legal outcomes, generally within the system, and specifically within any line of case law.

The first factor concerns the nature and scope of the powers delegated to the Court by the Member States, as contracting parties. The Rome Treaty charges the Court with enforcing treaty rules, most importantly, against the contracting parties themselves, and it establishes further details of jurisdiction. Discretion is also built into the treaty: in addition to direct grants of authority to the Court by the Member States, the contracting parties have also delegated in a 'tacit' or 'implicit' manner. The Treaty, like all modern constitutions, is an incomplete contract, generated by what Milgrom and Roberts (1992) have called 'relational contracting'. The parties to it do not seek to fully specify their reciprocal rights and duties; instead, they broadly framed their relationship through establishing basic 'goals and objectives', outer limits on acceptable behavior, and procedures for completing the contract over time. Adjudication functions to clarify, over time, the meaning of the contract, and to monitor compliance.

The second factor is the mix of control mechanisms available to the contracting parties, vis à vis the Court. Direct controls are formal (they are established by explicit rules) and negative (they annul or authoritatively revise the court's decisions, or curb the court's powers). The following point can hardly be overemphasized: the decision rule that governs reversal of the Court's interpretations of the Treaty - unanimity of the Member States plus ratification - constitutes a weak system of control. Put differently, the ECJ operates in an unusually permissive environment when it interprets the Treaty. When it interprets secondary legislation, per- 
missiveness shrinks in those domains governed by majority or qualified majority voting, other things equal. ${ }^{8}$

Indirect controls operate only insofar as the judges internalize the interests of the contracting parties, or takes cues from the revealed preferences of the latter, and act accordingly. The extent to which any court does so is commensurate to the credibility of the threat that direct controls will be activated. Given that the system of direct controls favors the ongoing dominance of the ECJ over the constitutional evolution of the system, we have no good reason to think that the ECJ, when it interprets the treaties, will be systematically constrained, in its use of its discretionary powers, for fear of being punished.

Taken together, these first two determinants constitute a strategic 'zone of discretion'. This zone is defined as (a) the sum of powers delegated from by the Member States to the Court, or possessed by the Court as a result of its own accreted rulemaking, minus (b) the sum of control instruments available for use by the Member States to shape (constrain) or annul (reverse) outcomes that emerge as the result of the Court's performance of its delegated tasks. Compared with most courts in the world, the ECJ operates in a zone of discretion that is unusually large when it interprets the Treaty. When the Court interprets the Treaty, its discretionary powers are close to unlimited.

Conceptualizing discretion in this way cannot tell us what the ECJ will actually do with its powers. The question - what values are judges maximizing when they exercise discretion? is a central one, if we are to make sense of European legal integration and the impact of the construction of the legal system on non-legal actors. I proceed on the assumption - implicitly shared by nearly all legal scholars who have sought to understand the dynamics of legal integration - that the Court seeks to enhance the effectiveness of EC law in national legal orders, to expand the scope of supranational governance, and to achieve the general purposes of the treaty broadly conceived. The Court cares about compliance with its decisions because compliance serves these values. I see no compelling or a priori institutional reason how one could justify modeling the Court (or the European judiciary) as servants of national governments. Where governments work to promote the same values, they work in tandem with judges; where they do not, they court judicial sanction.

The third determinant of the Court's discretion is endogenous to the Court's own decisionmaking, that is, relative levels of discretion will vary as a function of the Court's case law, but only if some minimally robust idea of precedent governs the Court's decision-making. The capacity of the Court to organize integration prospectively depends on its success in generating a relatively coherent jurisprudence on the Treaty. Of course, in elaborating 
ating a relatively coherent jurisprudence on the Treaty. Of course, in elaborating constraints that bind all actors in the EU system, the Court also constrains itself.

\section{Agency and Trusteeship}

At first glance, the discussion in the last section appears to fit easily with the so-called 'positive theory' of delegation. The analyst typically begins with an exposition of the underlying functional logics for delegation, in order to 'explain' why 'principals' delegate to 'agents' (new organizations). The standard line is that delegation is functional for principals insofar as delegation reduces the costs associated with governing: of bargaining and commitment; of monitoring and enforcing agreements; and of developing rational policies in the face of technical complexity, incomplete information, and powerful incentives for rent-seeking. The analyst then turns to how the principal-agent (P-A) relationship is constructed, focusing on the mix of ex ante and ex post incentives and control mechanisms that principals use (a) to preprogram the agent's performance with respect to their policy preferences, and (b) to monitor and punish the agent for non-performance.

There are good reasons to be dissatisfied with this approach to delegated governance (see Moe, 1987; Pierson, 1996; Thatcher and Stone Sweet, 2002), two of which I note here. First, the P-A framework loses much of its relevance in situations in which the agent's task is to govern the principals, and when the agent's rulemaking is effectively insulated from ex post controls. Following Majone (2001), when one analyses situations in which 'relational contracting' and commitment problems have induced political rulers to delegate broad 'fiduciary' powers to a particular kind of agent - a trustee - and then to guarantee that the latter's independence, the agency metaphor is less appropriate than one of trusteeship. The ECJ, like other European constitutional courts, is just such a trustee (Stone Sweet, 2002a), given that the relevant 'political property rights' (Moe, 1990) have been transferred to the Court.

The second problem relates to testing. The 'positive theory of delegation' offers appropriate, but pre-packaged, logics that can be applied to virtually any governance situation at the EU level. As causal theory, it remains woefully inadequate, unless the analyst clearly specifies variables or causal mechanisms that would make the formulation of testable hypotheses or comparative research on governance-through-delegation possible (Huber and Shipan, 2000). Most important, because the framework fetishises the ex ante functional needs of principals, it is poorly equipped to deal with the evolutionary dynamics of agency, let alone trusteeship.

Any theory of integration must attend to the motivations of the Member States in choosing to establish or enhance the powers of supranational organizations. Functional logics can help us to do so. They can also help to generate some very general expectations about how the system of governance constituted by delegation is likely to evolve. A trustee, for example, will 
likely to exert more independent impact on the evolution of EU institutions than will an agent. The Court operates in an expansive zone of discretion, and its activities - such as its interactions with national judges and private parties - cannot be directly controlled by the Member States. Ultimately, trusteeship constitutes a necessary condition for feedback and spillover to emerge and become entrenched. Constitutionalization, to which we now turn, expanded the Court's zone of discretion in very important ways.

\subsection{The Constitutionalization of the Treaty of Rome}

The constitutionalization of the European Community refers to the process by which the Rome Treaty evolved from a set of legal arrangements binding upon sovereign states into a vertically integrated legal regime conferring judicially enforceable rights and obligations on legal persons and entities, public and private, within EC territory. The phrase thus captures the transformation of an intergovernmental organization governed by international law into a multi-tiered system of governance founded on higher-law constitutionalism. Today, legal scholars and judges conceptualize the EC as a constitutional polity, and this is an orthodox (but by no means unanimous) position, although it also accommodates strong anxiety about the constitution's aesthetic imperfections, and its weak legitimacy. The ECJ has implicitly treated the Treaty as a constitutional text from the start; and, in 1986 (Parti Écologiste 'Les Vert' v. European Parliament, ECJ 294/83, 1986), the Court began to refer to the treaties as a "constitutional charter", or as "the constitution of the Community" (Fernandez Esteban, 1994).

It cannot be stressed enough that the Court initiated and sustained this process in the absence of express authorization of the Treaty, and despite the declared opposition of Member State governments (Stein, 1981). National governments could have blocked or reversed the process, but only by revising the Treaty of Rome. Treaty amendment requires the unanimous vote of the Member States, acting as a constituent assembly, followed by ratification in each member state, according to diverse procedures, including referenda. The Court's trustee status served to shield the process from direct interference on the part of the Member States. At the same time, constitutionalization strengthened the Court's position as trustee, expanding the zone of discretion of both the Court and national judges.

Moravcsik (1998) as well as Tsebelis and Garrett (2001), if for different reasons, have pointedly argued that the activities of the EC's supranational organizations have never produced 'unintended consequences' from the point of view of the Member States; for extended critiques of these positions, see Farrell and Héritier (2003) and Stone Sweet and Sandholtz (2002). The constitutionalization of the Treaty of Rome, of course, is an 'unintended consequence' of monumental proportions. 
The Member States neither provided for the supremacy of the Rome Treaty in national legal orders, nor for the direct effect of Treaty provisions and EC directives. Instead, they designed an enforcement system that I would characterize as 'international law plus', the 'plus' being (a) the compulsory nature of the Court's jurisdiction, and (b) the participation of a supranational authority - the Commission - in various proceedings. Under Art. 227, ${ }^{9}$ a Member State may bring a complaint against another Member State; if the Commission determines that the complaint is founded, and if the defendant state refuses to settle, the case could go to the Court. Art. 227 is a virtual dead letter, having been used on only a handful of occasions, producing not one important ruling on the part of the ECJ.

Under Art. 226, ${ }^{10}$ the Commission may initiate 'infringement proceedings' - also called 'enforcement actions' - against a Member State for non-compliance with EC law; rounds of negotiation with the government then ensue; if these fail, the Commission may refer the matter to the Court for decision. The Commission is under no obligation to bring proceedings; its discretion under Art. 226 is absolute. The Commission was reticent to use Art. 226 aggressively until the late-1970s, a posture it gradually abandoned as legal integration through Art. 234, and EC rulemaking (harmonization), proceeded. The Treaty of European Union added a new provision (to Art. 228) enabling the ECJ to fine Member States for failure to comply with an enforcement ruling. ${ }^{11}$

Art $234,{ }^{12}$ the linchpin of legal integration, was not intended to be an enforcement mechanism at all, although that is exactly what it became. Art. 234 established a procedure connecting the ECJ to the national courts. National judges make references to the European Court in order to obtain a formal interpretation of EC law - either of the Treaty, or of secon-

9 Article 227 EC: "A Member State which considers that another Member State has failed to fulfill an obligation under this Treaty may bring the matter before the Court of Justice. Before a Member State brings an action against another Member State for an alleged infringement of an obligation under this Treaty, it shall bring the matter before the Commission. The Commission shall deliver a reasoned opinion after each of the States concerned has been given the opportunity to submit its own case and its observations on the other party's case both orally and in writing. If the Commission has not delivered an opinion within three months of the date on which the matter was brought before it, the absence of such opinion shall not prevent the matter from being brought before the Court of Justice."

10 Art. 226 EC: "If the Commission considers that a Member State has failed to fulfill an obligation under this Treaty, it shall deliver a reasoned opinion on the matter after giving the State concerned the opportunity to submit its observations. If the State concerned does not comply with the opinion within the period laid down by the Commission, the latter may bring the matter before the Court of Justice".

11 The relevant provision states: "If the Court of Justice finds that the Member State concerned has not complied with its judgement, it may impose a lump sum or penalty payment on it". The first Member State to be fined under this provision was Greece (Commission v. Greece, ECJ C-387/97, 2000).

12 Art. 234 EC: "The Court of Justice shall have jurisdiction to give preliminary rulings concerning [...] the interpretation of this Treaty [and] the validity and interpretation of acts of the institutions of the Community [...]. Where such a question is raised before any court or tribunal of a Member State, that court of tribunal may, if it considers that a decision on the question is necessary to enable it to give judgment, request the Court of Justice to give a ruling thereon. Where any such question is raised in a case pending before a court or tribunal of a Member State, against whose decisions there is no judicial remedy under national law, that court or tribunal shall bring the matter before the Court of Justice". 
dary legislation - when EC law is material to the resolution of a case at bar. The ECJ's interpretation, called a 'preliminary ruling', is then applied by the judge of reference to resolve the case. The provisions were designed to help national judiciaries avoid conflicts of interpretation, thereby promoting the consistent application of EC law within national legal orders. The Member States did not mean to give citizens a means of suing their own governments, or of defending themselves against prosecution. Nor did they mean to confer on national judges the power of judicial review of national legislation with respect to 'higher' EC law. These outcomes, it turned out, inhered in the ECJ's vision of an integrated Community legal order.

The constitutionalization process has been driven primarily by the relationship between private litigants, national judges, and the ECJ, interacting within the framework provided by Art. 234. In the 1962-79 period, the Court secured the core, foundational principles of supremacy and direct effect. The doctrine of supremacy, first announced in Costa (ECJ 6/64, 1964), lays down the rule that, in any conflict between an EC legal rule and a rule of national law, the former must be given primacy. Indeed, according to the Court, every EC norm, from the moment of entry into force, "renders automatically inapplicable any conflicting provision of [...] national law" (Simmenthal, ECJ 106/77, 1978), including national constitutional rules. Where the doctrine of direct effect holds, EC norms confer - directly upon individuals - legal rights that public authorities must respect, and which can be pleaded in the national courts. During this period, the ECJ found that provisions of the Rome Treaty (Van Gend en Loos, ECJ $26 / 62,1963$ ) and a class of secondary legislation, called 'directives' (Van Duyn, ECJ 41/74, 1974), were, under certain conditions, ${ }^{13}$ directly effective. This latter move provoked a great deal of controversy, including heavy criticism from Member State governments (Craig and De Burca, 2003: 204), since the wording of the Treaty (Art. 249) strongly implies that EC directives only acquire their legal force in national law once they have been fleshed out and transposed by national executive or legislative authorities. ${ }^{14}$ The 'regulation', the other major form of secondary legislation, is the only EC legal norm that the Member States meant to be directly applicable within national legal orders (Art. $249 \mathrm{EC}$ ). The supremacy of EC law was further reinforced by the doctrine of preemption (e.g. Kramer, ECJ 3/76, 1976), which holds that where the EC's competence to act is exclusive, the taking of measures by the Community deprives national authorities of their powers to act independently.

These doctrines - insofar as national judges accept them - integrate national and supranational legal systems, and establish a decentralized enforcement mechanism for EC law. The mechanism relies on the initiative of private actors, enabled by the doctrine of direct effect.

13 The conditions are that the rights and duties created by the directive must be 'precise' and 'unconditional', and not depend upon further action by the Member States or EC legislative bodies.

14 Art. 249 EC: "In order to carry out their task and in accordance with the provisions of this Treaty, the European Parliament acting jointly with the Council, the Council and the Commission shall make regulations and issue directives [...]. A regulation shall have general application. It shall be binding in its entirety and directly applicable in all Member States. A directive shall be binding, as to the result to be achieved, upon each Member State to which it is addressed, but shall leave to the national authorities the choice of form and methods [...]." 
Direct effect is actually shorthand for a complex set of rules and principles of construction. As a point of law, the Court distinguishes between 'vertical' and 'horizontal' direct effect. Vertical direct effect refers to the capacity of Community law to create rights that individuals may invoke against national governments - and virtually all other public authorities - in disputes before a national judge. The Treaty, EC regulations, and EC directives can produce such effects. Horizontal direct effect refers to the capacity of Community law to create rights and obligations between any two private individuals or companies. Provisions of the Treaty and of EC regulations produce such effects, which allow, for example, a firm to sue another firm on the basis of such provisions, or an employee to sue an employer. After skirting the issue for a decade, the ECJ decided, in Marshall I (ECJ 152/84, 1986), that EC directives were not directly effective horizontally, that is, between two private parties. The Court's posture has been heavily debated, and may appear as an anomaly, however justifiable, ${ }^{15}$ in its otherwise consistent record of pushing hard to enhance the effectiveness of EC law within national legal orders. The Court subsequently resisted opportunities to reverse itself (e.g. Dori, ECJ C-91/92, 1994), choosing instead to develop other instruments to pressure governments to properly implement directives in a timely fashion. Direct effect, of course, depends on supremacy for its efficacy. The doctrine of supremacy prohibits public authorities from relying on national law to justify breaches of EC law, and it requires national judges to resolve conflicts between national and EC law in favor of the latter.

In a second wave of constitutionalization, the Court supplied national courts with enhanced means of guaranteeing the effectiveness of EC law. In Von Colson (ECJ 14/83, 1984), the doctrine of indirect effect was established, according to which national judges must interpret national law in conformity with EC law. In Marleasing (ECJ C-106/89, 1990), the Court clarified the meaning of indirect effect, holding that when a Member State has not transposed a directive, or has transposed it late or incorrectly, national judges are obliged to interpret the entire relevant corpus of national law as if it were in conformity with the directive. The doctrine thus requires national judges to interpret national statutes in ways that render EC law applicable, and thereby effective for individuals, even in the absence of implementing measures. Once national law has been so (re)constructed, EC law, in the guise of a de facto national rule, can be applied in legal disputes between private legal persons. The doctrine of indirect effect partly mitigates the problem that EC directives are not horizontally effective. In Francovich (ECJ C-6 and 9/90, 1991), the Court went even further, announcing the doctrine of state liability. According to this rule, a national court can, among other things, hold a member state financially responsible for damages caused to individuals due to the transposition been held to be horizontally directly effective, firms or individuals could have been held responsible for failure to comply with, say, an improperly implemented directive, even though compliance with the directive would mean contravening national law on the books. Further, until the Treaty on European Union entered into effect, the EC was not required to publish directives, which would have placed a serious burden on private actors to continuously monitor the activities of the EC legislator. 
or implementation failures. The national court may then require member states to compensate such individuals for their financial losses. As subsequently clarified in Brasserie du Pecheur (ECJ C-46 and C-48/93, 1996), individuals are entitled to reparation where Community law is "intended to confer rights upon them, the breach is sufficiently serious, and there is a direct causal link between the breach and the damage sustained by the individuals". Where state liability is found, it is up to the national court to assess damages (normally determined by the domestic law of remedies).

The ECJ has thus imagined a particular type of relationship between the European and national courts, a working partnership in the construction of a rule-of-law Community. In that partnership, national judges become agents of the Community order - they become Community judges - whenever they resolve disputes governed by EC law (Maher, 1994). The Court obliges national judges to uphold the supremacy of EC law (even against conflicting statutes, and even where parliamentary sovereignty otherwise holds sway); encourages them to make references concerning the proper interpretation of EC law to the Court; and empowers them, even without a referral, to interpret national rules so that these rules will conform to EC law and to set aside national law that does not.

The effectiveness of the system, therefore, depends critically on the willingness of national judges to refer disputes about EC law to the ECJ, and to settle those disputes in conformity with the Court's case law. Although national judges embraced the various logics of supremacy with differing degrees of enthusiasm, by the end of the 1980s every supreme court in the EC had formally accepted the doctrine (Slaughter, Stone Sweet and Weiler, 1998). Although judicial adaptation to constitutionalization has neither been simple nor painless, the ease with which judges at the Member State level were able to accommodate supremacy deserves to be assessed against the slower - and more conflictual - consolidation of supremacy in the United States federal system (Goldstein, 2001).

\section{The European Court and the National Courts}

Beyond the founding of the EC itself, the single most important institutional innovation in the history of European integration has been the constitutionalization of the Treaty of Rome. The $\mathrm{ECJ}$, in complicity with national judges and private litigants, constructed the legal system on the basis of a sustained commitment to making EC law effective within national legal orders. The outcome depended critically on the development of a working partnership between the ECJ and the national courts. This relationship has been the subject of a great deal of scholarly debate, the best of which combines doctrinal analysis with a concern for the strategic context in which the ECJ and the national judges find themselves. Some scholars (especially Weiler, Burley, Mattli) have focused primarily on the logics of cooperation between the European Court and national judges, others on conflict (Alter, 2001; Stone Sweet 1998; 2000). Those involved in the debate recognize that the relationship has been extremely complex 
and fluid, and that - in the absence of more systematic data and analysis - our attempts to understand its underlying features and dynamics are, at best, stylized simplifications of reality.

Cooperation received the earliest attention, as a puzzle to be explained theoretically. In most national jurisdictions, accepting supremacy meant abandoning deeply entrenched, constitutive principles, such as the prohibition against judicial review of legislation; direct effect required many judges to set aside traditional rules of standing and recognition, and to evolve new ones. Supremacy forbade the use of the standard dualist solutions to conflicts between national and international law, such as the lex posteriori doctrine and other corollaries of parliamentary sovereignty. Direct effect enables private actors to sue Member States governments for non-compliance with EC law, including failure to implement EC secondary legislation; such suits potentially pit judges against governments and the parliaments they control. Accepting supremacy thus entailed significant, non-incremental adaptation on the part of national legal orders. Given vast potential for conflict, how was it that constitutionalization nonetheless proceeded steadily, even dramatically?

A first approach to solving the puzzle proceeds on the assumption that judges seek to empower themselves: given the opportunity, judges will work to enhance their own authority to control legal and, therefore, policy outcomes, and to reduce the control of other institutional actors, such as national executives, parliament, and other judges. The Court's supremacy doctrine, combined with the procedures established by Art. 234, provided such an opportunity. Two academic lawyers (Stein, 1981; Weiler, 1981; 1991; 1994) pioneered thinking on the strategic choice-contexts facing European judges, and Weiler's own ingenious solution to the puzzle became the standard point of departure for others. Weiler argued that (a) constitutionalization of the Treaty and (b) the incentive structure in place for national judges pushed in the same expansive, integrative direction. National judges could acquire, many for the first time, the power to control state acts previously beyond their reach, such as statutes. Art. 234 not only legitimized what would become a complicit relationship between the ECJ and the national courts; it also afforded both judicial levels a good deal of protection from potential political fallout. The European Court responds to preliminary questions, as the Treaty requires, but the ECJ does not apply EC law within the national legal order; the national courts provide the ECJ with case load, but only 'implement' the Court's preliminary rulings, as the Treaty requires. Thus, at critical moments, each court can claim to be responding to the requirements of the law, and the demands of the other court. Once national judges understood that they were advantaged by participating in the construction of EC law, the delicate mixture of the active and the passive in this new legal system flowed naturally, gluing the two levels together.

A second set of approaches (Burley and Mattli, 1993; Stone Sweet and Brunell, 1998a), emphasizes the role of transnational and other private actors in activating and sustaining European legal integration; the ECJ and at least some national judges are assumed to have an 
interest in expanding transnational society and in expanding the domain of supranational governance. Litigants and their interests are understood to be fueling a machine operated by judges. In this view, legal integration develops a self-sustaining logic. In announcing the doctrines of supremacy and direct effect, the ECJ opened up the European legal system to private parties, undermined certain constitutional orthodoxies in place in Continental legal systems, and radically enhanced the potential effectiveness of EC law within the Member States. Private actors, motivated by their own interests, provided a steady supply of litigation capable of provoking Art. 234 activity. Preliminary references generated the context for judicial empowerment, which proceeded in the form of a nuanced, intra-judicial dialogue between the ECJ and national judges on how best to accommodate one another. And, as the domain of EU law expanded, this dialogue intensified, socializing more and more actors private litigants, judges, and politicians - into the system, encouraging still more use.

My own variation on this approach does not rely on judicial empowerment (Stone Sweet and Brunell, 1998b). The core claim is that judges who handle relatively more litigation in which EC law is material will be more active consumers of EC law, and more active producers of preliminary rulings, than would those judges who are asked to resolve such disputes less frequently. This formulation assumes that national judges seek to do their jobs well and effectively, that is, they would like to leave their courts at the end of their week having resolved more, rather than fewer, work-related problems. As the percentage of cases involving EC law rises, so do judicial incentives to master the tools that are most appropriate for the job, and those tools have been supplied by the European Court. Judges that need these tools less will be slower or more reticent to master them, and they will have less reason to be concerned with helping to guarantee the effectiveness of EC law. The approach helps us to explain some of the temporal variation found within Member States, between autonomous court systems. Across the EC civil law jurisdictions typically accepted supremacy more quickly and with fewer reservations than did, say, administrative law courts, and they produced far more references. As the scope of EC law gradually expanded into more areas, so did the willingness of national judges to make use of it.

It is important to stress that those who focused on intra-judicial cooperation and empowerment did not ignore intra-judicial friction, but took friction for granted as the expected state of affairs. The trick, then, was to explain why the legal system had nonetheless taken off. It is obvious that legal integration must be read partly as a narrative of how tensions have or have not been resolved (Stone Sweet, 2000; Weiler, 1994). Some of the most important achievements of legal integration - such as the progressive construction of a charter of rights for the EU - are rooted in deep, as yet unresolved doctrinal conflicts between the ECJ and national courts. It is also clear that positive incentives 'to play the Eurolaw game' do not apply to all judges, and that logics of empowerment can work in non-integrative ways (Stone Sweet, 1998a). National constitutional courts have good reasons to resist the development of a European 'constitutional' order that might subsume the national order (Stone Sweet, 2004). Other judges could foresee that the ECJ's case law might evolve in ways that would 
undermine their own carefully curated case law, autonomy, or relations with other national governmental bodies, and they might choose to ignore the Court's pronouncements. Further, the development of EU law would, in effect, expand the 'menu of policy choices' available to litigants and judges, and judges might exploit this development creatively, if not always in pro-integrative directions. In a recent book, Alter (2001) examines more systematically the reception of supremacy by French and German judges, paying full attention to the dynamics of intra-judicial conflict. ${ }^{16}$ She shows that there were multiple, overlapping, and everchanging reasons for how national judges chose either to make use of EC law, or to ignore it. The point accepted, the general trend has been clear: over time, national judges have been more not less willing to participate constructively in the construction of the legal system.

The focus of the book, The Judicial Construction of Europe, is on the impact of adjudicating EC law on the institutional evolution of the EU, rather than on the impact of EU law on (or the Europeanization of) national legal systems. How and to what effect national judges use EU law in their work remains a vast, largely unexplored area of research.

\subsection{The ECJ: Caseload and Rulings}

It has been mainly through its jurisdiction to process preliminary references (Art. 227) and infringement proceedings (Art. 226) that the European Court has registered its impact on integration, as well as on discrete policymaking episodes.

\section{Preliminary References}

Figure 7 plots the annual rate of Art. 234 references and rulings, beginning with the first in 1961. Without the doctrines of supremacy and direct effect, the level of preliminary references would doubtlessly have remained stable and low. In proclaiming supremacy and direct effect, the Court broadcast the message that EC law could be used, by individuals, businesses, and interest groups, to pursue their private interests. With use, firms and groups learned that Art. 234 could also be used to obtain policy outcomes that would otherwise have been impossible or more costly to obtain from executives and legislators. A victim of its own success, the system is today in deep crisis. Overloaded, the average delay between reference and $\mathrm{ECJ}$ ruling is now more than three years.

Figure 7: Annual Number of Preliminary References and Joined Cases

16 Inexplicably, Alter attacks all extant approaches for failing to notice intra-judicial conflict or to address the questions she has posed. However, the literature cited in this section focused squarely on supremacy conflicts (including Slaughter, Stone Sweet and Weiler, 1998, to which Alter contributed). 


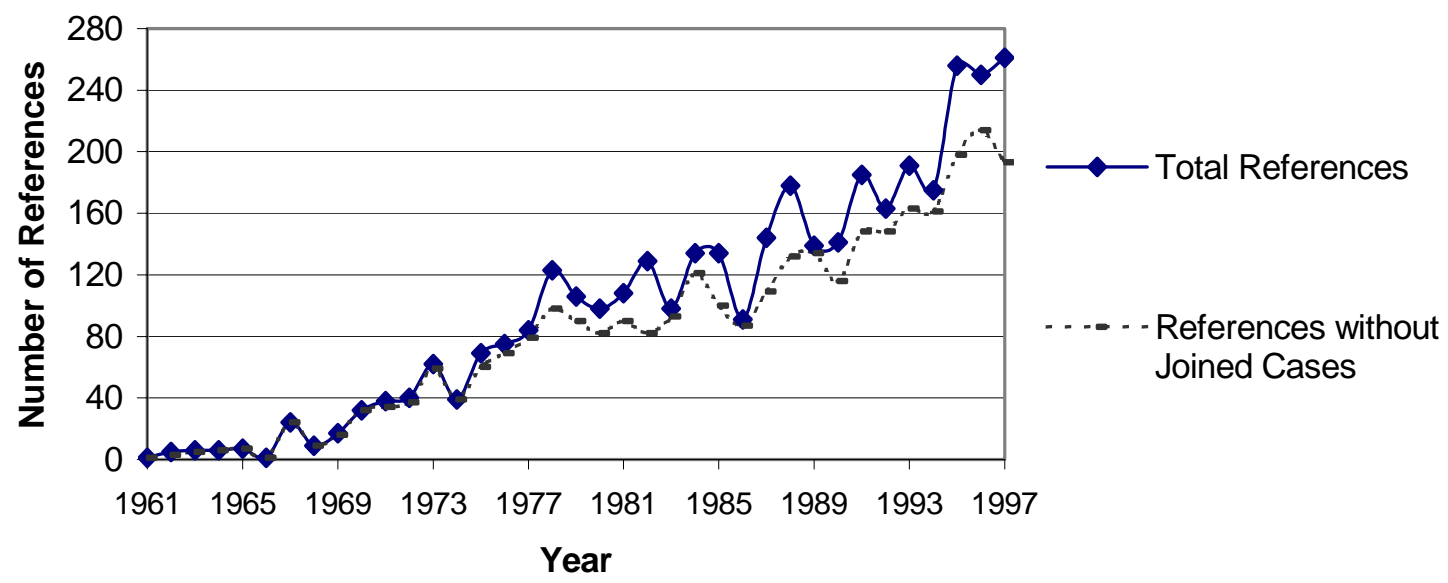

Note: The line plots the annual number of Article 177 references to the ECJ. The broken line plots the annual number of references minus those that have been joined to another case. The ECJ typically joins together references that are filed by the same judge, on the same day, involving the same legal dispute (although each involves a separate litigating party). The ECJ also joins pending cases, referred by different judges, when they involve the same legal dispute.

Source: Alec Stone Sweet and Thomas L. Brunell Data Set on Preliminary References in EC Law, 1958-98, Robert Schuman Centre for Advanced Studies, European University Institute (San Domenico di Fiesole, Italy: 1999). See Stone Sweet and Brunell (2000).

Table 1 provides domain-level data on preliminary references. I coded information on the domain being litigated using a reference system developed by the European Court. The Court classifies each reference in terms of the substantive issues raised by the referring judge, as issues are delineated by the Treaty. I sorted the references into the largest thirteen 'meta-categories' which, taken together, contain roughly $90 \%$ of the total number of domains invoked. Our dataset contains slightly more than 3,700 specific references, raising more than 4,700 separate substantive issues; judges often ask questions concerning more than one five domains. 
Table 1: Distribution of Preliminary References by Legal Domain and Period (Art. 234)

\begin{tabular}{|c|c|c|c|c|c|c|c|c|}
\hline & $\underline{1958-98^{*}}$ & $\underline{58-69}$ & $\underline{70-74}$ & $\underline{75-79}$ & $\underline{80-84}$ & $\underline{85-89}$ & $\underline{90-94}$ & $\underline{95-98^{*}}$ \\
\hline \multicolumn{9}{|l|}{ Subject Matter } \\
\hline \multirow[t]{2}{*}{ Agriculture } & $\%$ & 13.4 & 41.5 & 35.8 & 26.9 & 21.4 & 15.3 & 9.5 \\
\hline & $\mathrm{n} \quad 1,008$ & 13 & 129 & 232 & 202 & 170 & 163 & 99 \\
\hline \multirow{2}{*}{$\begin{array}{l}\text { Free Movement } \\
\text { of Goods }\end{array}$} & & 17.5 & 18.7 & 19.4 & 21.6 & 21.3 & 16.2 & 12.3 \\
\hline & 832 & 17 & 58 & 126 & 162 & 169 & 172 & 128 \\
\hline \multirow[t]{2}{*}{ Social Security } & & 26.8 & 10.3 & 12.2 & 7.9 & 8.9 & 10.2 & 6.5 \\
\hline & 444 & 26 & 32 & 79 & 59 & 71 & 109 & 68 \\
\hline \multirow[t]{2}{*}{ Taxation } & & 14.4 & 3.2 & 4.2 & 6.1 & 7.4 & 8.1 & 9.8 \\
\hline & 344 & 14 & 10 & 27 & 46 & 59 & 86 & 102 \\
\hline \multirow{2}{*}{ Competition } & & 12.4 & 7.1 & 4.3 & 4.9 & 5.5 & 10.5 & 6.1 \\
\hline & 318 & 12 & 22 & 28 & 37 & 44 & 112 & 63 \\
\hline \multirow{2}{*}{$\begin{array}{l}\text { Approximation } \\
\text { of Laws }\end{array}$} & & 1.0 & 1.0 & 1.5 & 4.9 & 4.2 & 3.9 & 8.9 \\
\hline & 217 & 1 & 3 & 10 & 37 & 33 & 41 & 92 \\
\hline \multirow[t]{2}{*}{ Transportation } & & 0 & 1.6 & 1.5 & 1.2 & 1.1 & 2.6 & 1.5 \\
\hline & 77 & 0 & 5 & 10 & 9 & 9 & 28 & 16 \\
\hline \multirow[t]{2}{*}{ Establishment } & & 1.0 & 1.9 & 3.7 & 2.1 & 6.4 & 8.4 & 9.8 \\
\hline & 289 & 1 & 6 & 24 & 16 & 51 & 89 & 102 \\
\hline \multirow{2}{*}{$\begin{array}{l}\text { Social } \\
\text { Provisions }\end{array}$} & & 0 & 0.3 & 1.2 & 2.8 & 3.9 & 8.5 & 8.2 \\
\hline & 236 & 0 & 1 & 8 & 21 & 31 & 90 & 85 \\
\hline \multirow[t]{2}{*}{ External } & & 1.0 & 2.6 & 2.3 & 3.1 & 1.8 & 1.6 & 3.0 \\
\hline & 109 & 1 & 8 & 15 & 23 & 14 & 17 & 31 \\
\hline \multirow{2}{*}{$\begin{array}{l}\text { Free Movement } \\
\text { of Workers and } \\
\text { Persons }\end{array}$} & & 1.0 & 2.9 & 2.9 & 2.9 & 5.2 & 3.7 & 6.8 \\
\hline & 202 & 1 & 9 & 19 & 22 & 41 & 39 & 71 \\
\hline \multirow[t]{2}{*}{ Environment } & & 0 & 0 & 0.2 & 1.7 & 1.0 & 1.0 & 4.1 \\
\hline & 75 & 0 & 0 & 1 & 13 & 8 & 10 & 43 \\
\hline \multirow{2}{*}{$\begin{array}{l}\text { Commercial } \\
\text { Policy }\end{array}$} & & 0 & 1.3 & 1.2 & 1.3 & 1.4 & 2.4 & 1.4 \\
\hline & 72 & 0 & 4 & 8 & 10 & 11 & 25 & 14 \\
\hline \multirow[t]{2}{*}{ Other Domains } & & 11.3 & 7.7 & 9.6 & 12.5 & 10.5 & 7.9 & 12.3 \\
\hline & 483 & 11 & 24 & 62 & 94 & 83 & 84 & 125 \\
\hline Total Claims & 4,706 & 97 & 311 & 649 & 751 & 794 & 1065 & 1039 \\
\hline $\begin{array}{l}\% \text { of Total Claims } \\
\text { by Period }\end{array}$ & $100 * \star$ & 2.1 & 6.6 & 13.8 & 16.0 & 16.9 & 22.6 & 22.1 \\
\hline
\end{tabular}

\footnotetext{
* The table contains information from the complete data set. The data for 1998 is incomplete, ending, for most countries, in May or June 1998.

** 'Joined references' (see fig. 1) are excluded from these calculations. Due to rounding, percentages of total claims by period add to $100.1 \%$.

Source:Alec Stone Sweet and Thomas L. Brunell Data Set on Preliminary References in EC Law, 1958-98, Robert Schuman Centre for Advanced Studies, European University Institute (San Domenico di Fiesole, Italy: 1999). See Stone Sweet and Brunell (2003).
} 
The table vividly records how Art. 234 activity has expanded in scope and intensity, across an increasing number of policy domains. During the 1970-74 period, over $60 \%$ of the questions raised in references fell in just two domains, agriculture and the free movement of goods; these areas today generate less than $20 \%$ of total activity. In the meantime, one observes an important diffusion of reference activity to other domains, such as environmental protection, taxation, commercial policy and competition, and the free movement of workers. Strikingly, in the 1990s nearly one-in-twelve references concerned sex discrimination law (which the Court codes as 'social provisions'). It is clear that as the scope of EU rules expanded, the legal system became not simply a vehicle for farmers, producers, and traders, but also for more diffuse, 'public' interests.

These data are relevant to one of the central claims of this book: negative and positive integration are linked to one another, notably through feedback loops that connect adjudicating and legislating. By definition, negative integration entails the removal of obstacles to transnational economic activity. To the extent that litigating trading rights under EC law serves to remove the most obvious hindrances to transnational exchange (border inspections, fees and duties, and so on), new obstacles to cross-border exchange will be revealed (laws and administrative practices designed to protect consumers, the environment, public safety, etc.). Traders can be expected to target these newly exposed strata of national regulatory systems in subsequent rounds of litigation. In this way, layers of the regulatory state can - potentially at least - be peeled away, like layers from an onion. I think of this dynamic as a kind of legal 'spillover', in that it has the potential to develop an expansive logic of its own. In fact (see Stone Sweet, 2004), by the late-1970s governments had discovered that adjudication in the area of free movement of goods area had exposed to challenge virtually any national rule that might affect intra-EC trade. Governments experienced mounting pressure to replace national regulatory regimes, even those designed to pursue otherwise legitimate public policy purposes, with supranational ones. Negative integration shaped how positive integration proceeded in these and other ways. At the same time, as the corpus of EC law grew more dense and articulated, so did the grounds for pleading rights under EC law in national courts. Other kinds of private actors litigated, including those not engaged in cross-border economic exchange or in market integration, per se. Some use Art. 234 overtly, for general policy purposes: to subvert local regimes, to replace national rules with more advantageous European ones, to enhance the role of the judiciary as an arena for policy innovation, and to reduce that of the national government and parliament. Legislating and litigating are thus connected in yet another way.

In part III of this paper, I summarize outcomes produced by the Court in one area of EC law: free movement of goods. 


\section{Enforcement Actions}

Figure 8 tracks the number of Art. 226 infringement proceedings and rulings, by period, since the Commission's first enforcement action (1961). The gap between the line plotting the number of proceedings and the line plotting the number of rulings represents the number of cases withdrawn from the Court's docket. In the vast majority of such instances, the Member State agrees to resolve the matter to avoid adjudication. The behavior makes good sense, since the European Court finds a breach of EC law by Member States in about $90 \%$ of its Art. 226 rulings, a success rate for the Commission that hardly varies across domains. Tables 2 and 3 provide domain-level information on infringement proceedings and rulings pursuant to Art. 226. For purposes of comparison, I have sorted enforcement actions into the same meta-categories as those used for preliminary references. Our database includes information on 1,406 individual proceedings, resulting in 801 rulings; each proceeding and ruling has been coded into a minimum of one, and a maximum of three, domains.

Figure 8: Annual Levels of Infringement Proceedings and Rulings

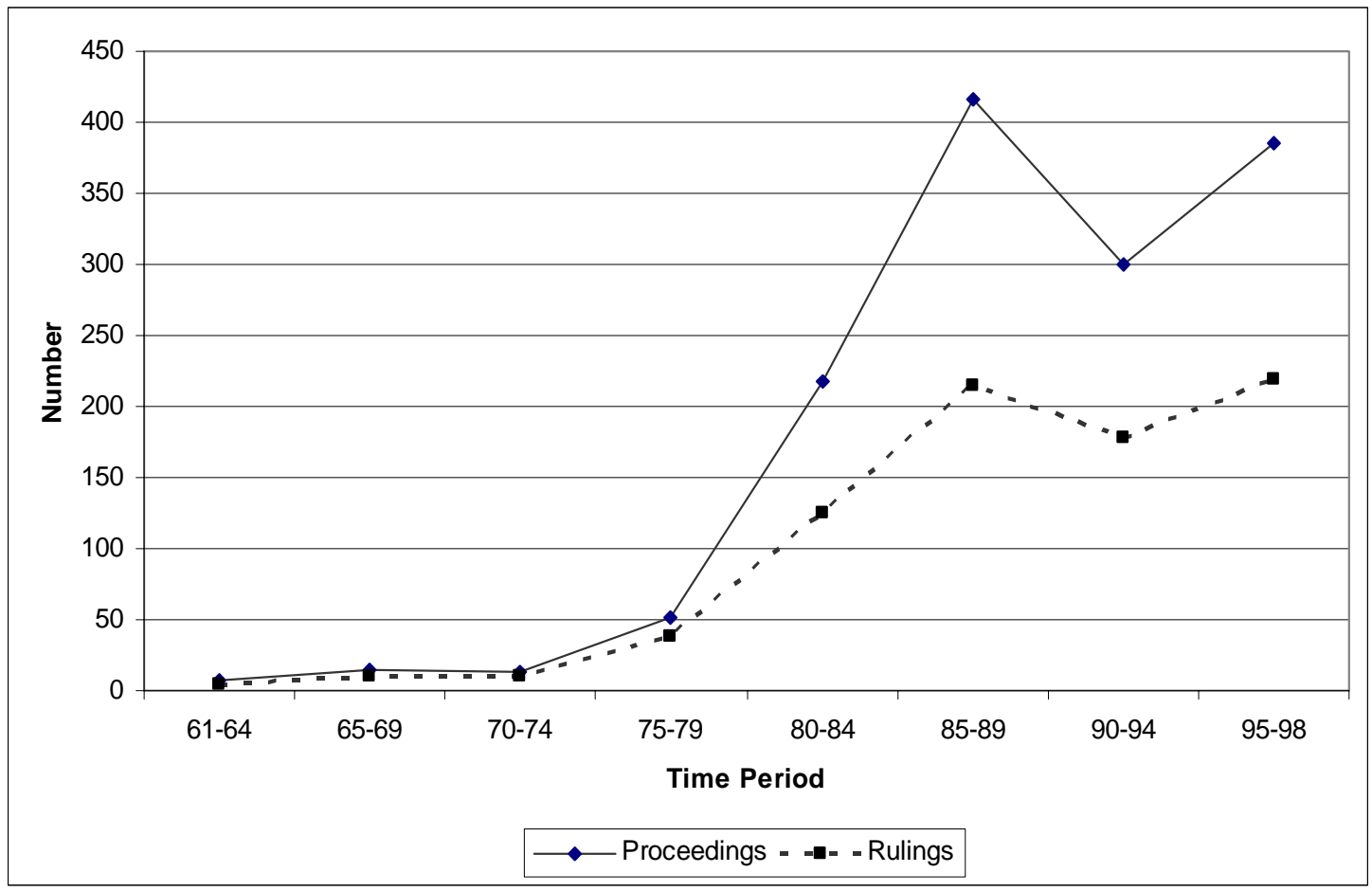

Source: Data compiled by Markus Gehring and Alec Stone Sweet from the European Court Reports, the Official Journal of the EC, and the Official Journal of the EU.

In practice, as Snyder (1996) notes, "the Commission can use litigation as an element in developing longer-term strategies. Instead of simply winning cases, it is able to concentrate 
on establishing basic principles or playing for rules" (see also Börzel, 2003). The Commission also uses its prosecutorial powers in the service of its legislative agenda. Prior to the signing of the Single Act, for example, it initiated a wave of proceedings based on the Court's expansive reading of Art. 28 (free movement of goods) to challenge national regulatory autonomy, and to give agency to its emerging mutual recognition strategy. At the same time, it began to prosecute Member States more aggressively for failures to properly implement EC directives governing the Common Market (approximation of laws). After 1986, this latter activity becomes the dominant source of enforcement actions, and free movement of goods proceedings drop off sharply. As the EC legislator pushed to 'complete' the internal market by 1992, it withdrew whole classes of potential disputes from the Court's free movement of goods docket, while making the politics of harmonization and implementation more salient.

Comparing Art. 226 and 227 - tables 1 and 2 - activity reveals some striking differences. Litigation in the sex equality (social provisions) domain has been driven by private parties using national courts under Art. 234, not by the Commission using Art. 226. That said, the Commission does not hesitate to prosecute Member States in the area, not least in order to force them to update their national law to conform to the Court's interpretations (Stone Sweet, 2004). In doing so, victims of sex discrimination are better positioned to use the national courts to vindicate their rights under EC law. In contrast, litigation in the environment domain is dominated by enforcement actions, accounting for between $10 \%$ and $20 \%$ of all Art. 226 activity since the 1985-89 period. Although preliminary references in the environmental protection field have grown steadily since 1980, to about $5 \%$ of all references today, restrictive standing rules, among other factors, has limited public interest litigation in the national courts (Stone Sweet, 2004). 
Table 2: Distribution of Infringement Proceedings by Legal Domain and Period (Art. 226)

\begin{tabular}{|c|c|c|c|c|c|c|c|c|}
\hline \multirow{2}{*}{ Subject Matter } & $\underline{1958-98^{*}}$ & $\underline{58-69}$ & $\underline{70-74}$ & $\underline{75-79}$ & 80-84 & $\underline{85-89}$ & $\underline{90-94}$ & $\underline{95-98^{*}}$ \\
\hline & & & & & & & & \\
\hline \multirow[t]{2}{*}{ Agriculture } & $\% 14.8$ & 16.0 & 28.6 & 24.7 & 13.6 & 13.8 & 16.4 & 13.6 \\
\hline & n 296 & 4 & 4 & 19 & 43 & 83 & 70 & 73 \\
\hline \multirow{2}{*}{$\begin{array}{l}\text { Free Movement } \\
\text { of Goods }\end{array}$} & 11.2 & 36.0 & 28.6 & 18.2 & 22.5 & 13.3 & 8.9 & 1.3 \\
\hline & 223 & 9 & 4 & 14 & 71 & 80 & 38 & 7 \\
\hline \multirow[t]{2}{*}{ Social Security } & 1.3 & 0.0 & 0.0 & 2.6 & 0.3 & 1.7 & 1.2 & 1.3 \\
\hline & 25 & 0 & 0 & 2 & 1 & 10 & 5 & 7 \\
\hline \multirow[t]{2}{*}{ Taxation } & 6.5 & 28.0 & 0.0 & 13.0 & 6.6 & 7.3 & 5.4 & 4.5 \\
\hline & 129 & 7 & 0 & 10 & 21 & 44 & 23 & 24 \\
\hline \multirow[t]{2}{*}{ Competition } & 2.8 & 8.0 & 7.1 & 5.2 & 3.8 & 3.0 & 2.3 & 1.7 \\
\hline & 56 & 2 & 1 & 4 & 12 & 18 & 10 & 9 \\
\hline \multirow{2}{*}{$\begin{array}{l}\text { Approximation } \\
\text { of Laws }\end{array}$} & 28.5 & 0.0 & 14.3 & 18.2 & 24.4 & 27.5 & 31.9 & 32.7 \\
\hline & 569 & 0 & 2 & 14 & 77 & 165 & 136 & 175 \\
\hline \multirow[t]{2}{*}{ Transportation } & 3.3 & 0.0 & 0.0 & 2.6 & 2.8 & 3.3 & 3.0 & 4.1 \\
\hline & 66 & 0 & 0 & 2 & 9 & 20 & 13 & 22 \\
\hline \multirow[t]{2}{*}{ Establishment } & 8.2 & 4.0 & 0.0 & 1.3 & 9.8 & 7.2 & 8.7 & 9.3 \\
\hline & 163 & 1 & 0 & 1 & 31 & 43 & 37 & 50 \\
\hline \multirow{2}{*}{$\begin{array}{l}\text { Social } \\
\text { Provisions }\end{array}$} & 2.6 & 0.0 & 0.0 & 0 & 4.4 & 1.5 & 2.1 & 3.7 \\
\hline & 52 & 0 & 0 & 0 & 14 & 9 & 9 & 20 \\
\hline \multirow[t]{2}{*}{ External } & 0.7 & 4.0 & 0.0 & 0 & 0.3 & 0.7 & 0.7 & 0.9 \\
\hline & 14 & 1 & 0 & 0 & 1 & 4 & 3 & 5 \\
\hline \multirow{2}{*}{$\begin{array}{l}\text { Free Movement } \\
\text { of Workers and } \\
\text { Persons }\end{array}$} & 2.7 & 0.0 & 7.1 & 1.3 & 0.6 & 2.5 & 5.2 & 2.4 \\
\hline & 54 & 0 & 1 & 1 & 2 & 15 & 22 & 13 \\
\hline \multirow{2}{*}{ Environment } & 10.6 & 0.0 & 0.0 & 6.5 & 4.7 & 9.7 & 8.9 & 17.9 \\
\hline & 212 & 0 & 0 & 5 & 15 & 58 & 38 & 96 \\
\hline \multirow{2}{*}{$\begin{array}{l}\text { Commercial } \\
\text { Policy }\end{array}$} & 0.2 & 0.0 & 0.0 & 0.0 & 0.0 & 0.2 & 0.7 & 0.0 \\
\hline & 4 & 0 & 0 & 0 & 0 & 1 & 3 & 0 \\
\hline \multirow[t]{2}{*}{ Other Domains } & 6.6 & 4.0 & 14.3 & 6.5 & 6.0 & 8.3 & 4.7 & 6.4 \\
\hline & 131 & 1 & 2 & 5 & 19 & 50 & 20 & 34 \\
\hline \multirow{2}{*}{$\begin{array}{l}\text { Total Claims } \\
\% \text { of Total Claims } \\
\text { by Period }\end{array}$} & 1994 & 25 & 14 & 77 & 316 & 600 & 427 & 535 \\
\hline & 100 *** & 1.3 & 0.7 & 3.9 & 15.8 & 30.1 & 21.4 & 26.8 \\
\hline \multicolumn{9}{|c|}{ * Based on filing dates (not date of decision). } \\
\hline \multicolumn{9}{|c|}{$\begin{array}{l}\text { ** Infringement proceedings can be filed in more than one issue area for the same case. The table counts domains not rulings. } \\
\text { There are 1,406 Art. } 226 \text { proceedings in our data set. }\end{array}$} \\
\hline \multicolumn{9}{|c|}{ 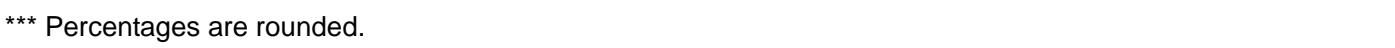 } \\
\hline
\end{tabular}


Table 3: Distribution of Art. 226 Rulings by Legal Domain and Period

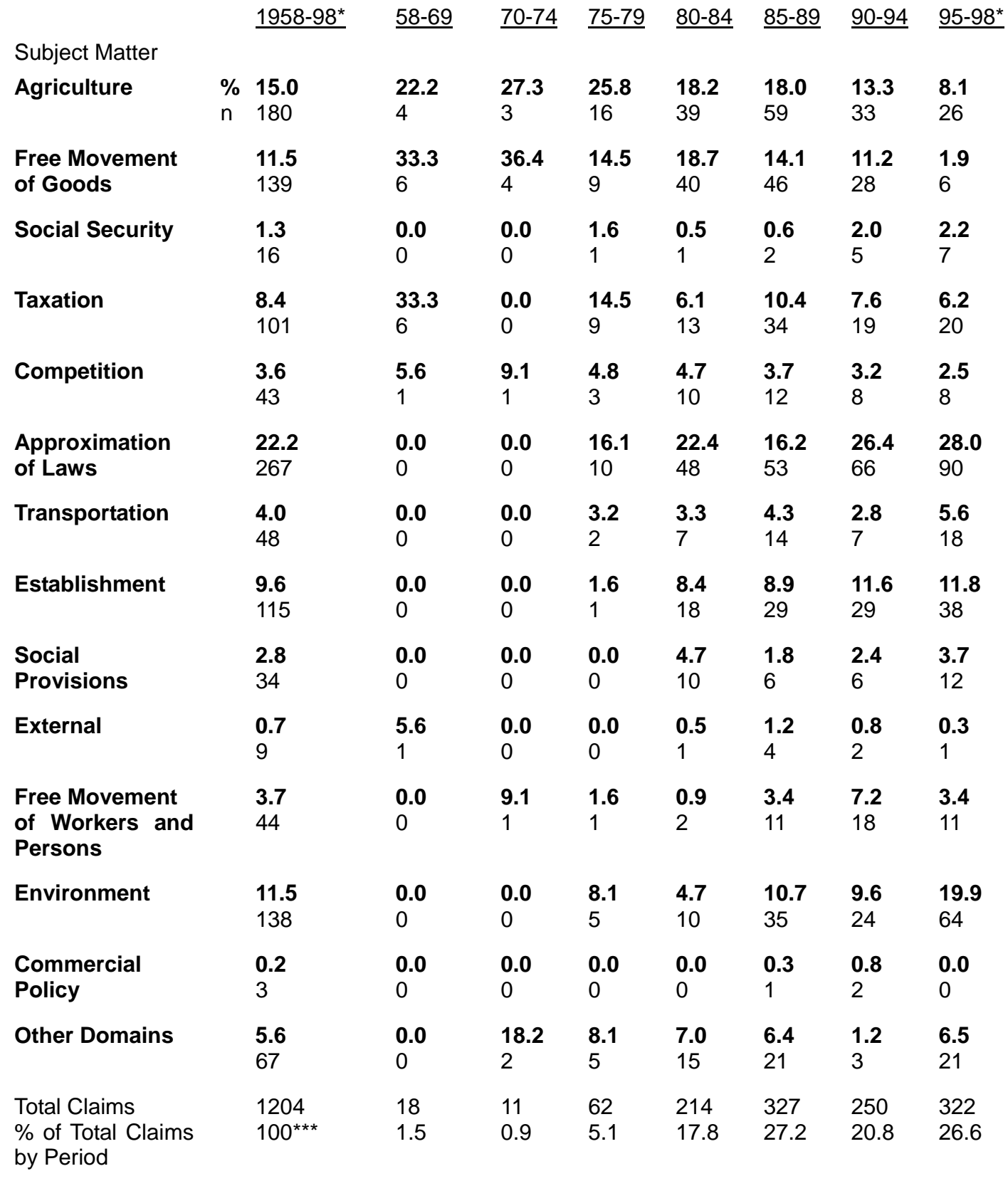

\footnotetext{
* Based on filing dates (not date of decision).

** Infringement proceedings can be filed in more than one issue area for the same case. The table counts domains not rulings. There are $801 \mathrm{ECJ}$ enforcement rulings in our data set.

*** Due to rounding, percentages of total claims by period add to $99.9 \%$.

Source: Data compiled by Markus Gehring and Alec Stone Sweet from the European Court Reports, the Official Journal of the EC, and the Official Journal of the EU.
} 


\section{The Free Movement of Goods}

In this section, I focus on the impact of the evolution of the Treaty of Rome's trading institutions on the EU system as a whole. The free movement of goods domain comprises the classic core of the market integration project, and the Court's jurisprudence on Art. 28 has rightly been the subject of sustained theory-driven doctrinal research (e.g. Poiares-Maduro, 1998; Weiler, 1999). In political science, the revival of integration studies (Sandholtz and Zysman, 1989) and rise of intergovernmentalist theory (Moravcsik, 1991; Garrett, 1992) began with a focus on the relationship between market-building, the legislative process, and treaty-revision. I summarize this episode primarily to test theory against data (for the full account, see Stone Sweet, 2004). Although I report results for the free movement of goods domain as a whole, my primary concern is on the knottiest problem of all: non-tariff barriers.

Given my theoretical priorities, I expected the adjudication of trading disputes in the EU to be patterned in predictable ways. ${ }^{17}$ One set of expectations concerned logics of litigating. Traders would use Art. 28 instrumentally, to remove national barriers to intra-EU trade, targeting disproportionately - measures that hinder access to larger markets relative to smaller ones. As negative integration proceeds (that is, to the extent that the legal system sides with traders against national authorities), further litigation will be stimulated. A second set of expectations concerned the kinds of outcomes the legal system would be likely to generate. Given a steady supply of preliminary references, it will be the Court's case law, and not the preferences or decision-making of Member State governments, that determines how the domain evolves. On the basis of assumptions about litigants' and judges' interests, the Court can be expected to produce rulings that (a) facilitate expansion of intra-EU trade, (b) undermine national control over such activity, and (c) press the EU's legislative bodies to extend the scope of the polity's regulatory capacities. These expectations are conditioned by the Court's zone of discretion in this area: the Court is a trustee of the Treaty, not an agent of national governments.

Alternative propositions have been put forward. Garrett (1992) argued that the Court's decisions would serve to codify, in case law, the policy interests of the dominant states. In a follow-up piece, Garrett (1995) argued that the Court seeks to enhance its own legitimacy by pursuing two, sometimes contradictory, goals: (a) to curry the favor of powerful states, and (b) to ensure member-state compliance with its decisions. The ECJ, he argued, will sometimes censure 'powerful governments', but only in 'unimportant sectors' of the economy, while 'accepting protectionist behavior' in more important sectors, since strong governments are unlikely to comply with adverse decisions. Apparently, no stable predictions are derivable

17 Hypotheses are derived and tested more formally in Stone Sweet and Brunell, 1998a; Stone Sweet and Caporaso, 1998; Fligstein and Stone Sweet, 2002. 
when it comes to 'less powerful governments'. As in all his work, Garrett resolutely ignores the litigants and national judges, a choice left undefended.

Unfortunately, it is all but impossible to derive relevant testable propositions from Moravcsik's most recent version of intergovernmentalism. Since the Member States established the authority of the Commission and the Court in the free movement domain through purposive acts of delegation, their activities serve the fulfillment of the Member States' grand designs. Nonetheless, Moravcsik makes at least one straightforward causal claim, in the guise of the assertion that delegate governance has never produced 'unintended consequences'. He insists (1998), that while governments set the agenda for the EU's organizations, the latter never "alter the terms under which governments negotiate new bargains". The argument is repeated (1998) in his analysis of the Single European Act (SEA).

\subsection{Art. 28 of the Treaty of Rome}

The Rome Treaty required the Member States to eliminate national barriers to intra-EC trade by the end of 1969, including non-tariff barriers. Article 28 states that "Quantitative restrictions on imports and all measures having equivalent effect (MEEs) shall be prohibited between member-states". Article 30 permits a Member State to derogate from Article 28, on grounds of public morality, public policy, public security, health, and cultural heritage, though derogations may "not [...] constitute a means of arbitrary discrimination or a disguised restriction on trade between Member States". In ex-Art. 33, the Member States charged the Commission with producing directives to fix a 'procedure and timetable' for states to abolish MEEs. Compared with import quotas or border inspection fees, non-tariff barriers - MEEs negatively affect intra-EU trade in less visible, more indirect ways; further, being part of national regulatory regimes, they can always be justified as serving legitimate state purposes. In the system designed by the Member States, MEEs were to be removed through two mutually-reinforcing processes: states would abolish such measures on their own, or be pushed to do so by infringement proceedings, while the EC legislation would gradually replaced national regulations with 'harmonized' ones.

On the eve of the entry into force of free movement of goods provisions, this system was in deep trouble. Member States had made little effort to abolish MEEs on their own, and the Luxembourg Compromise (important EC legislation was to be adopted by unanimity voting in the Council of Ministers, rather than through qualified majority, applicable from 1966), threatened to paralyze the Commission's harmonization efforts. To jumpstart matters, the Commission issued Directive 70/50 (December 1969), pursuant to ex-Article 33 (reproduced in Oliver 1996: 424-28). The Directive gave Art. 28 an expansive reading. First, it listed nineteen types of rules or practices that Member States were to rescind, including discriminatory policies on pricing, access to markets, advertising, packaging, and names of origin. Pushing further, it announced what we will refer to as a 'discrimination test': measures that treated domestic 
goods differently than imported goods - say, by limiting the availability or the marketing of imports, or by giving 'to domestic products a preference' in the domestic market - were prohibited under Art. 28. Second, the Commission raised the sensitive question of the legality of measures that states applied to domestic and imported goods equally, but were nonetheless protectionist. The Directive proposed that such 'indistinctly applicable measures' [IAMs] ought to be captured by Article 28 , if they would fail a test of proportionality. Where the "restrictive effects of such measures [...] are out of proportion to their [public policy] purpose", and where "the same objective can be attained by other means which are less of a hindrance to trade", the IAM constitutes an illegal MEE. With Directive 70/50, the Commission had gone far beyond its remit. The Member States had not delegated to the Commission the power to define the legal concept of MEEs, nor had they ever meant for Art. 28 to apply to IAMs. Note, however, that the Commission, while being an agent of the Council of Ministers in the harmonization process, is a trustee of the Treaty under ex-Art. 33.

In a series of rulings responding to references from national judges, the Court superseded the Commission on the first point, and absorbed the second, elaborating a highly intrusive form of judicial review of national regulatory regimes in the process. In Dassonville (ECJ 8/ 1974), the Court announced that "all trading rules (later replaced by "all measures") [...] capable of hindering directly or indirectly, actually or potentially" intra-EC trade constitute MEEs. Traders bear no burden to show that a national measure actually reduces levels of exchange, or is de facto equivalent to a quota (the position defended by most if not all Member States at the time). In subsequent cases, the Court not only formally required national judges to apply a least-means/proportionality test to claimed exceptions under Art. 30, but sometimes did the balancing for the judge of reference, thereby determining the outcome (the classic case is De Peijper, ECJ 104/1975). In Cassis de Dijon (ECJ 120/78), the Court extended the Dassonville framework and least-means balancing to IAMs, that is to the whole of national regulatory regimes, a move tempered somewhat by making available a new set of justifiable derogations from Art. 28. Claimed Art. 28 derogations are available to states only in areas of regulation that have not been harmonized, and are subject to strict proportionality review. Last, in now famous dicta, Cassis suggested that the treaty implied, and perhaps required, what came to be known as the 'mutual recognition' of national production and marketing standards.

\subsection{The Emergence and Consolidation of the 'Dassonville Framework'}

The basic doctrinal structure governing free movement of goods developed quickly, in a series of cases decided in the 1970s. The crucial elements of the framework are the following: First, trader's rights are conceived broadly and expansively, while the prerogatives of national governments are conceived restrictively. Second, there exist no clear limits to the reach of judicial authority into national regulatory regimes. Third, through the enforcement of a least-means, proportionality test, the framework makes judges the ultimate masters of 
trade law. Thus, the doctrinal structure encourages traders to use the courts as a means of negative integration, while denying that national authorities possess secure political property rights when it comes to the regulation of market activities. Perhaps most important, since the framework authoritatively organized the relationship between Articles 28 and Articles 30, it also per force organizes a discursive politics on the nature of European constitutionalism and the limits of national sovereignty (see Poiares Maduro, 1998).

\section{Dassonville: Hindrance to Trade, Direct or Indirect}

The Dassonville case $(E C J$ 8/74, 1974) provided the Court with its first important opportunity to consider the meaning of free movement of goods provisions.

In 1970, Mr. Dassonville imported a dozen bottles of Johnnie Walker Scotch Whiskey into Belgium, after having purchased it from a French supplier. When Dassonville put the scotch on the market, he was prosecuted by Belgian authorities for having violated customs rules. The rules prohibited the importation from an EU country, in this case France, of spirits that originated in a third country, in this case Britain, unless French customs rules were substantially similar to those in place in Belgium. Dassonville was also sued by a Belgian importer who possessed, under Belgian law, an exclusive right to market Johnnie Walker. Dassonville argued that, under Article 28 of the Treaty, goods that had entered France legally must be allowed to enter Belgium freely, and that exclusive rights to import and market goods were not valid. The Belgian court appeared to agree and requested guidance from the ECJ.

Dismissing the objections of the UK and Belgium, both of which argued that such rules were not prohibited by Article 28, the Court found for Dassonville. Much more important, the Court declared the following:

All trading rules enacted by the Member States, which are capable of hindering, directly or indirectly, actually or potentially, intra-Community trade are to be considered as measures having an effect equivalent to quantitative restrictions.

With no supporting argument, the Court had repudiated the two rival understandings of Article 28 then current. In its official brief to the Court, the UK had argued that only measures that actually result in a "quantitative reduction in the movement of goods" might be captured by Article 28. The UK's position, which would have placed the burden on the trader-plaintiff to show that a given national measure had caused direct, deleterious effects on trade, had wide support among the Member States and legal scholars at the time (see Oliver, 1996). With Directive 70/50, the Commission had sought to destroy this interpretation. The Court replaced the Commission's discrimination model with its own, even more rigorous, 'hindrance to trade test'. If put to a vote, the ECJ's interpretation of Article 28 - more expansively integrationist than any in circulation at the time - would certainly not have been accepted by the Member State governments. 
The Court had, after all, placed no limits to the reach of Article 28: all national laws or administrative practices that negatively impact the activities of traders, including those that do so only 'indirectly or potentially', are presumptively prohibited. This Court had thus raised a delicate political issue, which proved inseparable from how the law would come to develop. The wholesale removal of national regulations would strip bare legal regimes serving otherwise legitimate public interests, such as the protection of public health, the environment, and the consumer. Further, where the Council was unable to produce harmonized legislation in a timely fashion, this lack of protection might not only endure, but could weaken public and political support for integration down the road. In response, the ECJ announced, in Dassonville and subsequent decisions, that the Member States could, within reason, continue to regulate the production and sale of goods in the public's interest, pending harmonization by the EU's legislator. The Court stressed that: (a) the condition of 'reasonableness ${ }^{18}$ would be controlled strictly; (b) such regulations - as with national measures justified under Article 30 grounds - could not "constitute a disguised restriction on trade between member states"; and (c) the European judiciary would review the legality of these exceptions to Article 30 on a case-by-case basis.

Thus, not only did the Dassonville decision define Article 28 as broadly as possible, it laid the foundations for balancing, and therefore for judicial dominance over trade policy within the EU.

\section{De Peijper: Least-Means Proportionality}

The ECJ's ruling in Dassonville showed traders that litigation of Article 28 in the national courts could be an effective means of subverting national laws that hurt them, and of shaping the evolution of EU institutions in their favor. At the time, the legal establishment (in Brussels, Luxembourg, and the academy) still clung to the idea that the appropriate way to review breaches of Treaty law by the Member States was through infringement proceedings organized by the Commission (Article 226 EC). The Court, however, had made it clear that the rights of traders must be defended by national judges, and that national judges must do so in particular ways. Most important, Dassonville requires national judges to assess the reasonableness of national measures that might affect trade. In De Peijper, the Court (ECJ 104/75, 1976) demonstrated that such a requirement entails the judicial review of the decisionmaking of national lawmakers, in micro-detail if necessary. 
The case concerned criminal charges brought by Dutch prosecutors against an importer of the pharmaceutical, Valium. Mr. De Peijper had distributed the Valium to a hospital and pharmacy, after having purchased it from an English wholesaler and repackaged it under his own company's name. He was accused of violating a law that prohibited the marketing of medicinal products without the prior consent of the Public Health Inspector, in the absence of certain documents, to be verified by the Inspector, certifying the origin and composition of imported medicines. In his defense, Mr. De Peijper pleaded Article 28. He could do so since the files and reports required by the Public Health Inspector could be completed only by designated 'experts' who, in practice, were pharmacists employed by a company that was also the official importer of Valium into the Netherlands. Since Mr. De Peijper's company sold Valium at a lower cost than the official importer, he believed he would not be able to obtain the latter's help in completing the required documents. The national court of referral asked the ECJ if the measures in question, as applied to parallel imports, constituted a 'measure having an equivalent effect' under Article 28 and, if so, whether the measure could be justified on Article 30 grounds, namely, under the heading of 'public health'. Once the oral proceedings before the ECJ had been completed, the Commission instituted infringement proceedings against the Netherlands, under Article 226.

The Advocate General sided with the importer, noting that Valium circulated lawfully in other Member States, under various licenses and other public controls, which could in principle be used by national authorities to trace origin. The Dutch and British governments defended the measures in question, first as non-discriminatory, then on Article 30 grounds. But they also argued, joined by the Danish government, that the measures simply implemented existing EU directives, and thus were presumptively valid under EU law. These directives prohibited the marketing of 'medicinal products' in the absence of "a prior authorization issued by the competent authority in the Member State"; and they obliged distributors of imported medicines to show to this authority documents, to be completed with the aid of designated 'experts', certifying the product's "composition and the method of preparation". In response, the Advocate General argued that the case implicated only the relationship between Articles 28 and 30, and that EU secondary legislation could not expand the scope of "the residuary powers left to the Member States by Article 30".

A final issue concerned the judicial function of the preliminary reference procedure, relative to infringement proceedings. In his report, the Advocate General $(642-43,649)$ noted:

Although it is not within the scope of the Court's jurisdiction under Article 234 to give a ruling on the compatibility of the provisions of a specific national law with the Treaty, it acknowledges [...] that it has jurisdiction to provide the national court with all the factors of interpretation under Community law which may enable it to adjudicate upon this compatibility.

"There is no doubt", the Advocate General continued, "that the normal way of testing the compatibility of national laws [with EU law] is by means of [...] Article 226", rather than 
through a reference from a national court. Yet, he argued, "if the Court wishes to give a helpful answer to the national court", it would be "impossible for it [...] to avoid examining this problem of compatibility". Further, given his expressed view on how the case ought to be decided, "the question then arises how Netherlands law should be adjusted in order to encourage free trade to the greatest possible extent while complying with the well-known requirements of public health". The Advocate General suggested that the Court could avoid the question for now, leaving it to be resolved through the Commission's infringement proceedings.

The Court ruled that the Dutch measures fell within the purview of Article 28, taking care to restate the Dassonville formula. It then proceeded to balancing, generating an explicit leastmeans test:

National rules or practices do not fall within the exception specified in Article 30 if the health and life of humans can be as effectively protected by measures which do not restrict intra-Community trade so much.

The ECJ then insisted that the national court apply such a least-means formula to resolve the case.

The Court could have ended the matter there. Instead, it chose to evaluate the proportionality of the Dutch measures on its own, showing how a Member State might secure the public's interest in ways that would hinder trade less than the Dutch rules at hand. Among other solutions, the Court suggested that national authorities "adopt a more active policy" of helping traders acquire necessary information, rather than "waiting passively for the desired evidence to be produced for them", or making importers dependent upon a competitor. More broadly, a Member State could hardly claim to be acting to protect public health, the Court declared, if its policies discouraged the distribution of lower cost medicines. Finally, the Court ruled that the various EU directives harmonizing regulation of pharmaceuticals had no effect on the scope of Articles 28 and 30.

De Peijper illustrates some crucial aspects of the dynamics of judicial balancing under leastmeans proportionality tests. Courts do not enforce such tests without reenacting the decision-making processes of those whom they are being asked to control. That is, "they [...] put themselves in the latter's shoes, and walk through these processes step-by-step" (Stone Sweet, 2000: 204). Inevitably, judges speak to how governmental officials should have behaved, if the latter had wished to exercise their authority lawfully. In doing so, judges lay down prospective rules meant to guide future decision-making. Lawfulness, balancing courts are telling policymakers, entails reasoning through the legal norms as judges do, as balancers of rights against the public interest. Not surprisingly, ongoing enforcement of leastmeans tests tends to generalize judicial techniques of governance, inducing other public officials, if they hope to defend their interests adequately, to engage in the style of argumentation developed in the pertinent case law (Stone Sweet, 2000). 
The De Peijper ruling supplemented Dassonville in ways that quickly locked in these dynamics with respect to European market integration. The Court served notice to the Member States that national regulations bearing on trade could only be justified under the most restrictive of conditions. It demonstrated to litigators and the Commission that the preliminary reference procedure comprised an effective means of reviewing the conformity of national with EU law, parallel to, but not restricted by, the infringement procedure. And the ECJ ordered national judges to engage in least-means testing, while promising to instruct them exactly how to do so, where necessary.

\section{Cassis: Mutual Recognition and Strict Scrutiny of Mandatory Requirements}

A third seminal ECJ decision, Cassis de Dijon (ECJ 120/78, 1979), completed the construction of a comprehensive framework for adjudicating trade disputes under Article 28. With Directive 70/50, the Commission had sought to bring within the ambit of Article 28 IAMs: those national measures that did not, on their face, discriminate between domestic and imported goods, but which nonetheless restricted market access to imports, or otherwise disadvantaged them relative to domestic goods. In Cassis, the Court extended the Dassonville principles to this class of national regulation. Put very differently, the Court had decided that traders should not be asked to bear the costs of the Member States' failure to produce harmonized EU market rules.

In 1976, the German federal agency that regulates the marketing of spirits denied a request to import the French liqueur, Cassis de Dijon, a black currant syrup typically mixed with wine as an aperitif, because its alcohol content fell below a minimum that would, under German law, allow it to be sold on the German market. Restated in general terms, the national judge asked the ECJ if Article 28 could cover national laws that fixed different mandatory requirements for the marketing of products relative to those in place in other Member States. In its defense, the German agency claimed that IAMs were not presumptively captured by Article 30, referencing Commission Directive 70/50 in support. In the absence of harmonization through EU directives, counsel for the German agency argued, "each Member State retains full legislative jurisdiction over the technical characteristics upon which the marketing of beverages and foodstuffs is made conditional". As a second line of defense, the agency dutifully trotted out arguments to the effect that its rules on alcohol content served various public interests, covered under various headings of Article 36. The Advocate General rebutted each of these arguments in his report, stating, notably, that the Court had rejected the more 'limited interpretation' of Directive 70/50 being relied on by the defendant.

The Court agreed with the German agency that where harmonized rules were not in place, "it is for the Member States to regulate all matters relating to the production and marketing of [...] alcoholic beverages [...] on their own territory". However, it also ruled that "disparities between the national laws" that hinder trade in such products would be "accepted only in so 
far as [such laws] may be recognized as necessary [...] to satisfy mandatory requirements relating in particular to the effectiveness of fiscal supervision, the protection of public health, the fairness of commercial transactions, and the defense of the consumer". After rehearsing and dismissing each of the justifications given by the German agency, the Court then declared that it could not divine:

[any] valid reason why, provided that they have been lawfully produced or marketed in one of the member states, alcoholic beverages should not be introduced into any other member states.

Through dictum, the Court had floated a new principle: that of the mutual recognition, on the part of each Member State, of the national production and marketing standards in place in the other Member States.

The Court's judgment extended the logic of Dassonville, while innovating in several important ways. With Cassis, no aspect of national regulatory policy touching on the market for goods could be considered, a priori exempt from judicial scrutiny. The ruling required national judges to attend to the effects, on traders, of 'disparities' between national legal regimes, thus making them supervisors of the politics of harmonization. At the same time, the Court made available to the Member States a new set of justifications for derogating from Article 28 , although these are valid only in the absence of harmonization. ${ }^{19}$ In subsequent cases, the Court imposed a least-means proportionality test to scrutinize such claims, which it taught to national courts by way of example.

\section{Precedent}

This trio of founding cases produced a set of general doctrinal principles that governed the domain until its partial mutation in the 1990s (discussed briefly below). In our analysis (Stone Sweet and McCown, 2003) of the structure of the system of argumentation in the domain, we found that over 1/3 of all of the Court's Art. 234 decisions on MEEs under Art. 28 cite at least one of these three rulings. Of those rulings that combine multiple arguments from more than one decision, more than $1 / 2$ do so. As adjudication in the area proceeded, litigators and judges developed increasingly refined structures - derivations of the basic principles - for dealing with particular problems. Litigators learned to build arguments from rulings on trading situations that most resembled those in which they found themselves; and the Court typically

19 In Cassis, the Court generated four possible derogations (for 'mandatory requirements' related to fiscal supervision, the protection of public health, the fairness of commercial transactions, and the defense of the consumer), which were later supplemented by two other headings: the improvement of working conditions, and the protection of the environment. Although the Court treats the source of these derogation to be Art. 28, each is nonetheless subject to exactly same judicial standards of scrutiny as are justifications claimed by the Member States under Art. 30. 
treats these arguments, and its own precedents, at relatively sectorally-based. For example, intellectual property rights decisions tend to draw on previous cases dealing with trademark and copyrights questions, rather than advertising or labeling requirements, even when the legal question at issue deals with rather general balancing rules that are applied in the same way in all free movement of goods disputes. At the same time, a precedent-based discourse on the various justified exceptions to Article 28 also developed, which varies subtly across the Article 30 headings and the mandatory requirements under Article 28.

The development of a minimally-coherent, precedent-based discourse on Art. 28 is a necessary condition for the range of outcomes - feedback effects of the Court's case law - to which we now turn.

\subsection{Outcomes}

The Court's case law on Art. 28 combined with the doctrines of supremacy and direct effect to give traders rights that were enforceable in national courts. After Cassis, no part of the regulatory state was a priori insulated from the reach of judicial review. Although important, the production of favorable doctrines does not conclude the story. The more the EU's legal system actually removes barriers to markets, for example, the more intra-EU trade and subsequent litigation will be stimulated. Positive outcomes for traders will attract more litigation, negative outcomes will deter it. Further, the more effective the legal system is at enforcing Art. 28, the more pressure adjudication puts on the EC's legislative organs to harmonize market rules. I now turn to the dynamic effects of this doctrinal structure on the greater integration process, culminating in the Single Act.

Figure 3 depicts the annual number of Article 234 references for the domain as a whole, and for Art. 28, through mid-1998. References have steadily increased since Dassonville, and spike upward after Cassis. Breaking down the data cross-nationally shows that only two of the original EU-6, France and Germany, have generated a disproportionate number of references in this legal domain. ${ }^{20}$ Of the original EU-12, French, German, Italian, and UK judges have produced $73 \%(591 / 805)$ of all references in the domain. Trader-litigators, in fact, do target large markets, relative to smaller ones. The finding seems unsurprising: traders have a far greater interest in opening larger markets relative to smaller ones; and higher levels of cross-border trade, strongly correlated with larger markets, will generate relatively more trading disputes than would smaller markets (see Stone Sweet and Brunell, 1998a). In contrast, Garrett $(1992 ; 1995)$ claimed that the ECJ and the legal system only work effectively against smaller states. 
Figure 9: Annual Number of Preliminary References - Free Movement of Goods

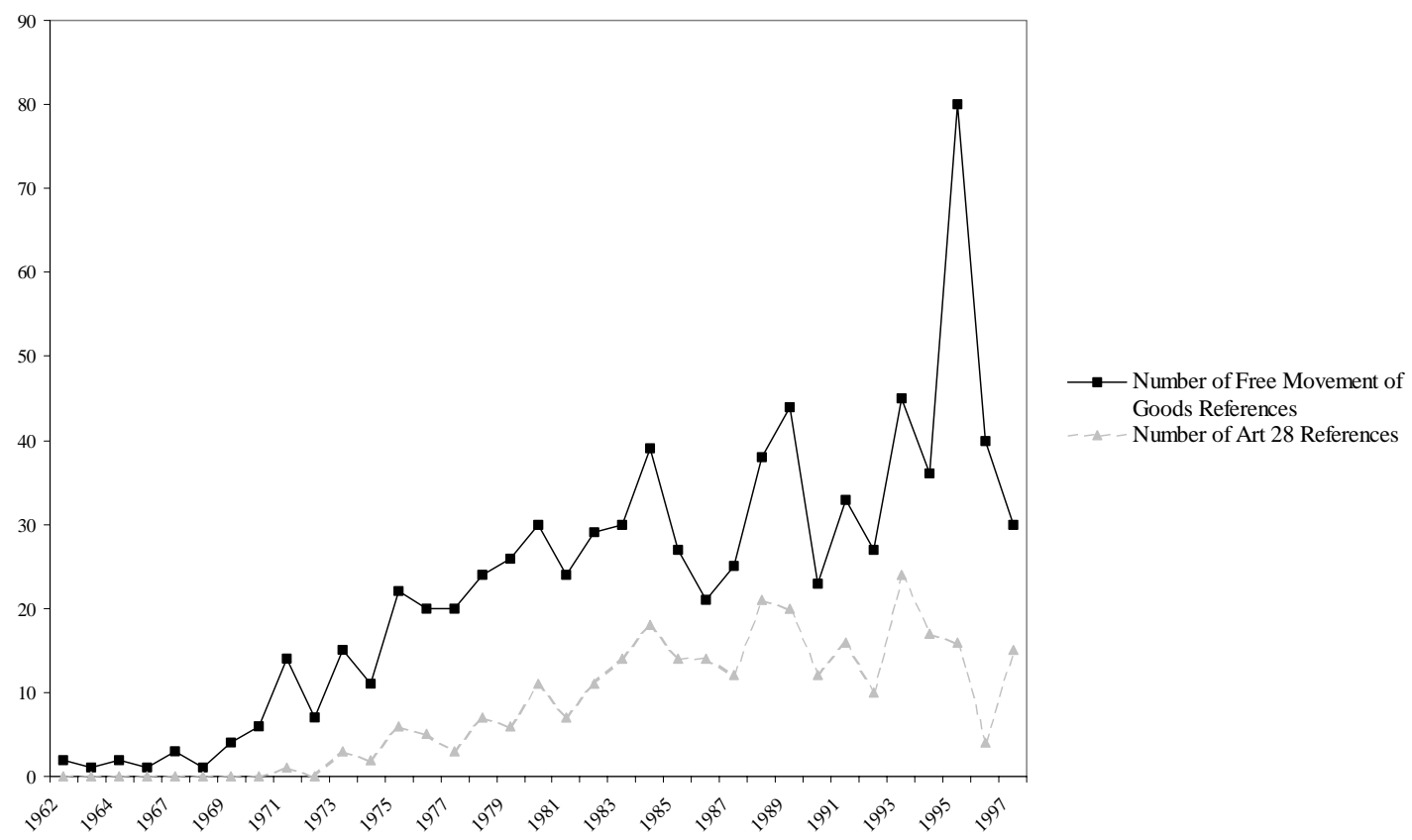

Source: Alec Stone Sweet and Thomas Brunell Data Set on Preliminary References in European Law, 1958-98, Robert Schuman Centre for Advanced Studies, European University Institute (San Domenico di Fiesole, Italy), 1999. See Stone Sweet and Brunell (2000).

Analysis of the dispositive outcomes produced by the Court provides a more direct test of such claims. We examined all of the ECJ rulings pursuant to Art. 234 references that expressly invoked Art. $28(n=254)$. For each ruling, we coded for whether the Court declared the type of national rule or practice at issue to be a violation of Art. 28 , or not. The ECJ ruled in favor of the trader-plaintiff in exactly half of all decisions in which such a determination was clearly made (108/216). Traders have a higher success rate in France, Germany, and Italy - well over $50 \%$ - than they do in Belgium, the Netherlands, and the UK; and they enjoy the best success rate $(60 \%)$ in Germany. Member State briefs to the Court - revealed state preferences on how the Court should decide cases - failed to presage, or influence, the Court's rulings. German interventions were found to be particularly ineffectual in generating outcomes (see also Kilroy, 1996). In contrast, the Commission's observations 'predicted' the Court's decision about $85 \%$ of the time. Thus, there is no evidence to support the view that governments constrain the Court in any important, let alone systematic, way. Similarlydesigned studies of adjudicating EU social provisions and environmental protection confirm these results (Cichowski ,1998; 2001; Stone Sweet, 2004).

We also examined the types of national rules and practices that have come under attack in references, and the data show legal integration to be an inherently expansionary process. In the 1970s, the vast majority of references attacked national measures that required special 
certification and licensing requirements, border inspections, and customs valuations for imports. After Cassis, a host of IAMs, such as those that impose purity or content requirements, came onto the Court's agenda. By the early-1980s, traders began to attacking an increasingly broad range of national rules, such as those related more to the marketing (rather than the production) of goods: minimum pricing, labeling and packaging requirements, Sunday trading prohibitions, and advertising. The absence of any clear limit to the reach of Dassonville-Cassis made these dynamics - which progressive extended the reach of Art. 28 to more and more indirect hindrances to trade - possible.

Given the nature of least-means balancing, the ECJ and national judges inevitably came to play a powerful lawmaking role, not least in providing templates of lawful market regulation. In its Article 28 case law, the Court routinely generated such templates, which could then become harmonized law in one of two ways. National regimes could adapt themselves to the Court's case law, in order to remain competitive and to insulate themselves from litigation. Or, more efficiently, the Commission could propose legislation of the kind that had passed review by the Court, thus providing the Member States with legal shelter.

Both routes were facilitated by how the Court actually decided cases. In a very important piece of research, Poiares-Maduro (1998) examined how the ECJ balances (a) trading rights, against (b) derogations from Article 28 claimed by Member State governments, in that part of the domain governed by Cassis (i.e. the review of the conformity, with Art. 28, of IAMs). The data show that the judges engage, systematically, in what he calls "majoritarian activism" (1988: 72). When the national measure in question is more unlike than like those equivalent measures in place in a majority of Member States the ECJ strikes it down as a violation of Article 28 (we found that the Court began, in the early-1980s, to ask the Commission to provide such information on a regular basis). Poiares-Maduro found no exceptions to this rule. On the other hand, he found that the Court tends to uphold national measures in situations in which no dominant type of regulation exists, although there are important exceptions. In this way, the Court generates a 'judicial harmonization' process. Majoritarian activism undermines the logic of minimum common denominator outcomes asserted by intergovernmentalists. At the same time, the Court would have little to fear in the way of reprisals, since a majority of Member States would likely be on its side on any given case.

No systematic research on the relationship between the Court's Article 28 case law and legislative harmonization in the EU has been undertaken. It is, however, routinely noted that the Court replaced the Council of Ministers as a force for positive integration, prior to the Single European Act (Craig and De Burca, 1998; Oliver, 1996), and a smaller literature (Empel, 1992; Berlin, 1992) focuses on how the Court's caselaw required or provoked governments to act legislatively. In any case, dozens of EU directives adopted prior to the Single European Act codified, as secondary legislation, specific rulings of the Court. Much more attention has been paid to the impact of Cassis de Dijon, from which the Commission developed a new strategy for achieving market integration. 
Following the Court's ruling in that case, the Commission took the unusual step of issuing a 'Communication', in the form of a letter sent to the Member States, the Council, and the Parliament (reproduced in Oliver, 1996). The letter asserted that the Court had effectively established mutual recognition as a constitutional principle, which the Commission went on to interpret in the broadest possible manner. The Court had shown how states might retain their own national rules, capable of being applied to within the domestic market, while prohibiting states from applying these same rules to goods originating elsewhere. Reliance on mutual recognition could obviate the need for extensive harmonization. Indeed, the Commission announced, it would henceforth focus its harmonization efforts on IAMs, particularly those "barriers to trade [...] which are admissible under the criteria set by the Court". Almost immediately, the large producer groups and associations of European business proclaimed their support of the initiative, and the new strategy - mutual recognition, minimal harmonization came to be dominate the discourse on how best to achieve market integration.

Concurrently, the Commission began to use Art. 226 more aggressively, for the first time, in order to increase the pressure on governments. Prior to Cassis, the Court produced only two Art. 226 rulings on Art. 28. From the date that Cassis de Dijon was rendered to the date the Single Act was signed, the Commission filed 46 cases on Art. 28 leading to final judgements by the Court. Member States lost $85 \%$ of these cases. During this same period, the Commission formally filed 36 more Art. 28 suits against Member States that were subsequently withdrawn by defendant Member States that decided to settle before going to court. In the crucial 1980-84 period, free movement of goods cases comprised more than 1-in-3 of all Art. 226 rulings; and nearly $30 \%$ of all rulings concerned MEEs under Art. 28.

The literature on the sources of the Single European Act, of which mutual recognition was an important part, has sufficiently demonstrated the extent to which the EU's supranational organizations and transnational business were ahead of governments in the process of 'relaunching' Europe (Alter and Meunier-Aitsahalia, 1994; Dehousse, 1994; Fligstein and MaraDrita, 1996; Sandholtz and Zysman, 1989; Stone Sweet and Caporaso, 1998; Weiler, 1991; but Moravscik, 1991; 1995 disagrees). Governments acted, of course, in the form of a Treaty that codified integrative solutions to their own collective action problems, including the renunciation of the Luxembourg compromise. But these solutions had emerged from the activities of the EU's organizations and transnational actors, against the backdrop of pent-up demand for more, not less, supranational governance. Of course, the process was not only to do with transnational activity, law, courts, and trusteeship. It was propelled forward by a growing sense of crisis, brought on by globalization, the failure of go-it-alone policies to sustain economic growth, and an accumulation of legal precedents that empowered traders and the Commission in legal disputes with national administrations.

In his most recent account of the SEA, Moravcsik (1998) denies all of this, declaring that the EU's organizations "generally failed to influence the distribution of gains" that could have had an effect on the preferences of governments to negotiate. With respect to the im- 
pact of the Court and the legal system, what evidence does Moravcsik (1998) marshal to support this view? In my view, none. First, he does not discuss the sources and consequences of litigating Article 28 and related provisions, and thus is not in the position to address if or how adjudication "influence[d] the distribution of gains". During the crucial 1979-84 period, levels of Art. 226 and Art. 234 litigation under Art. 28 rose sharply; rulings of noncompliance proliferated; and national regulatory frameworks were placed in a creeping "shadow of the law". Second, Moravcsik (based on the error made by Alter-Meunier and Aitshalia, 1994 ${ }^{21}$ ) wrongly claims that Cassis was actually a "retreat from previous ECJ jurisprudence", but he does not defend the view. In fact, Cassis extends Dasssonville to IAMs, a deeply controversial area that governments had not contemplated being covered by the treaty until the Commission's 1970 directive. Third, he argues that mutual recognition "was not a new innovation", but had been floated as early as the late-1960s. Yet, if by Moravcsik's own admission, the governments knew of this proposal, they did not adopt it. Instead, they pursued an intergovernmental politics that continued to fail miserably. In the end, they adapted to Cassis, for obvious, 'rational' reasons, including the fact that the Court had constructed Art. 28 in ways that redistributed resources toward those actors pushing for more supranationalism.

Last, Moravcsik argues that (a) governments fulfilled their own 'demand' for mutual recognition and majority voting, and (b) "Cassis, at most, accelerated the single market program", but "was not a necessary condition". Since he nowhere specifies the conditions necessary for the SEA, it is not obvious how one might assess or respond to this claim. The Member States' 'demand' for mutual recognition and harmonized market regulations was heavily conditioned by outcomes produced by the legal system, and Moravcsik fails to show otherwise. The Court's steady and expansively integrationist interpretation of Art. 28 undermined national regulatory sovereignty, enhanced the role of transnational actors and national judges to participate in market integration, and empowered the Commission, in both legislative and judicial processes. Clearly, the 'distribution of gains', however conceived, had been altered, raising the cost of intergovernmental inaction considerably.

A broader point deserves emphasis. To take imperfect commitment and delegation in the EU seriously requires us to abandon an exclusive focus on governments, and to examine the dynamics of agency and trusteeship. In this story, the Member States did not design the EU's trading institutions, nor did they design the mode of governance that best served to enforce them. The Court did. When Cassis was rendered, the Legal Service of the Council of Ministers actually produced a finding that rejected the ruling's main principles, asserting the viability of the Commission's (pre-Dassonville, Directive 70/50) discrimination test! ${ }^{22}$ A simple

21 Alter and Meunier-Aitshalia (1994) emphatically claim that, beyond its dicta on mutual recognition, the Court's ruling does not innovate on the basic Dassonville framework. The error is critical, and it undermines their analysis of the ruling's impact. 
counterfactual might provide the best test: in a world without direct effect and supremacy, in a world in which the Member States actually controlled the evolution of the EU's trading institutions, how far would market integration have gone after the Luxembourg compromise?

\subsection{Mutation of the Dassonville Framework}

The Dassonville framework remained remarkably stable until 1993, when, in Keck (ECJ 167/1991), the Court removed national regulation of certain 'selling arrangements' from the corpus of IAMs covered by Art. 28 (see also Weiler, 1998). I view this decision as an adjustment dictated largely by the evolution of adjudication in the domain, that is, more to do with factors that are endogenous to the legal system's own activities rather than with exogenous factors. The aggressively interventionist approach taken by the Court in Cassis had led to three sets of interrelated problems. First, as noted above, in the 1980s market actors who were not primarily involved in intra-EC trade began to use Art. 28 to attack national regulations they did not like. This led to a great deal of doctrinal soul-searching about the absence of limits to the reach of Cassis, worries that we can assume were shared by the Court (Advocate General Van Gerven in Torfaen [ECJ 145/88]; Mortlemans, 1991; Steiner, 1992). In the end, the Court adopted the solution proposed in a beautifully-argued article (White, 1989) produced by a lawyer in the legal affairs department of the Commission. In Keck, the Court announced, the legal system would continue to monitor and enforce Art. 28 rules against one class of IAMs - mandatory requirements related to the characteristics of products - but would greatly reduce or abandon altogether the review of restrictions placed on the circumstances (i.e. the time, place, and manner) of selling goods. In essence, Keck tells a large class of potential litigants - merchants not directly engaged in importing or exporting goods that 'enough is enough'. Second, the Court was responding to signals from their most important interlocutors: the national courts. Many national judges had all but refused to subject IAMs to least-means proportionality testing. I examined, for the Cassis through Keck period, every national decision on IAMs reported by courts in three EC Member States (France, Netherlands, UK). Most judges, at least implicitly, used a discrimination test, not the 'actual or potential, direct or indirect' hindrance to trade test announced by Dassonville. In all three countries, national judges were often unwilling to enforce Art. 28 rules against the state when the litigant was not directly involved in moving goods across borders (see also Jarvis, 1998). Third, the marginal returns to market integration of an aggressive approach to IAMs had, by the time Keck was decided, fallen virtually to zero (see also Shapiro, 1999; Weiler, 1998). In my view, the approach was a victim of the Court's more general successes. After the Single Act, the legislative process opened up (see part I of this paper), and harmonization proceeded steadily, thereby withdrawing, prospectively, whole classes of cases from the Court's docket. The Court's role in market regulation has become less high-profile since, and necessarily so (as predicted by Weiler, 1991). 


\section{Conclusion: Integration, Constitutionalization, Eu- ropeanization}

Integration under the Treaty of Rome has proceeded now for more than four decades. The process has been punctuated by discrete events registered in political, economic, and legal domains of action. But these events have been embedded in a larger flow. European integration is fundamentally about how a large number of actors, operating in relatively separate arenas, were able to produce new forms of exchange and collective governance for themselves. Market actors, interest groups, national governments and administrators, the EU's organs, technical experts, the legal profession, and the courts have found themselves having to confront one another. It is remarkable how successful they have been in building new institutions, organizational capacity, and means of coordinating activities across fields and domains. The institutionalization of supranational governance has, in turn, pushed for more, not less, integration.

Today, national economies are highly integrated; market regulation reflects European rules; EC law holds sway over national law and administration; and interested parties continue to push for institutional innovation in Brussels and Luxembourg. Strikingly, half of world trade occurs within the borders of the EC, a share that will rise sharply with enlargement. Transnational networks of producers and public interest groups have oriented their activities toward Brussels. The EC's political organizations govern, by making, applying, and interpreting rules that are authoritative throughout the territory of the EC. National courts routinely enforce European law and coordinate EC and national regulatory regimes; and national parliaments and bureaucracies incorporate EC legislation into their procedures and practices. Member State governments have facilitated integration, at times proactively, but often only by being dragged along. Integration has been a powerful force because it has served to embed interests, investments, and identities, in a dynamic, expansionary way. It has done so by connecting arenas for economic, political, and legal decision-making, giving the system strength and resilience.

The analysis raises a critical question: to what extent did European integration have to proceed as it did? It might be possible to read this account in a primitive, 'functionalist', way: a preexisting configuration of actors and their preferences mixed with the Treaty of Rome and EC organs to produce, teleologically as it were, the main outcomes described. I would reject such an interpretation. European integration has been structured by crucial events that were not predictable from any ex ante historical moment. There is simply no good reason why the constitutionalization of the Treaty of Rome, or many other crucial events, had to happen. If national judges had ignored or rejected the Court's moves in the 1960s, the EC project would have floundered. If, in the 1980s, the Member States had refused to recommit to collective governance, based on enhanced supranationalism, the Single European Act would 
not have been negotiated and ratified. Traders and other organized interest groups played important roles in these transitions, not least by litigating and lobbying. But political actors, operating in the EC's legislative and judicial organs, ultimately produced the broader institutional terrain of the EC. If my collaborators and I have elaborated a dynamic causal account of integration, the theory is nonetheless a probabilistic one. ${ }^{23}$ Although I claim to have explained some of the most important features of European integration over time, I would deny that these outcomes were predetermined in any theoretically meaningful way.

The legal system has provided some - but by no means all - of the institutional underpinnings for what has happened. It has done so by engaging the decision-making of other actors, including governments, the Commission, and a growing variety of litigating parties.

There are a number of reasons why the constitutionalization of the Rome Treaty generated an expansive logic of its own, entailing an increasing demand for law, rule clarification, and capacities for monitoring and enforcement. From the beginning, the central mission of the EC was to create the conditions for the development of the Common Market. Yet impersonal exchange, across jurisdictional boundaries, is problematic for reasons that social scientists have explored at some length. As elsewhere, the success of integration has depended heavily on the extent to which the EC could develop effective organizational capacities: to guarantee property rights, to enforce competition rules, to adjudicate legal claims, to build a European framework for regulating market activities, and so on. At the very least, constitutionalization accelerated this process. In my view, one can go further: the ECJ authoritatively reconstituted the Community in ways that linked the demand for and supply of European law and courts to the activities of market actors, and then to all activities governed by EC law. Constitutionalization not only positioned the courts as primary arenas for negative integration; it made them supervisors of positive integration, and curators of a growing corpus of rights which the Court found in the Treaty itself.

In addition, the EC governs principally through making rules (directives, regulations, decisions), drawing affected groups into deliberative procedures (comitology and other modes of consultation); it has little capacity to govern through taxation, redistribution, and commandand-control. The EC has weak coercive capacities; the Commission succeeds by brokering interests, and arbitraging across domains and organizations; the administration and enforcement of EC law is typically left to national authorities. In consequence, modes of supranational governance tend to be heavily norm-based: legalistic but incomplete. To be effective, EC policies must be implemented and 'completed', which requires high levels of coordination across multiple levels of government. Judges are necessarily implicated in such a

23 The statistical tests of our propositions were sensitive to necessary but not sufficient conditions, and relationships among variables are always expressed as contingencies ('to the extent that'). See Fligstein and Stone Sweet, 2002; Stone Sweet and Brunell, 1998a. 
political system. With constitutionalization, the national courts, too, developed into privileged sites for deliberation and rulemaking, not least, because they are charged with supervising the transposition and implementation of EC law by national authorities. It is hardly surprising that, with the expansion of supranational governance and the consolidation of supremacy and direct effect, national administrative autonomy has been undermined, and judicial discretion enhanced. Subversion of national ways of doing things is not the whole story, however. As the scope of supranational governance has widened and deepened, government official operating at regional, national, and sub-national levels have themselves been led to adopt the kinds of rule-making practices and discourses under way in European policy arenas.

The recitation is not meant to imply that the Europeanization of national law and politics has proceeded mechanically, or without friction. If integration provokes Europeanization, the latter process has proceeded according to its own quite different logics. ${ }^{24}$ One important indicator of the success of the integration project is that scholars are now earnestly studying the Europeanization of national politics.

One can, of course, conceptualize Europeanization in different ways. For our purposes, we can define it as the impact of social and market integration (the development of transnational society) and supranational governance (EU rules, procedures, and the activities of EU organizations) on processes and outcomes taking place at the national level. The research is organized through specifying the dependent variable: impact will vary across time, policy domains, national organizations (or arenas), and across Member States or jurisdictions within states. The assertion is that the dependent variable of integration studies becomes the independent variable of Europeanization studies. Europeanization has partly been provoked by how the various modes of supranational governance have actually been institutionalized over time (Stone Sweet, Sandholtz and Fligstein, 2001). But we have only just begun thinking about how - through what social mechanisms or processes - such impact is registered. With constitutionalization, the judiciary has gradually evolved into a kind of central nervous system for the EU. It helps to regulate Europeanization in diverse ways, but there is nothing simple, 'natural', or robotic about how it does so. European legal integration - which is itself the first important form of Europeanization - has been and will always be a complex, messy process.

In the past decade, academic lawyers and social scientists have produced an impressive stack of studies documenting how individuals and groups have used EC law in the courts of the Member States in order to change local laws, administrative practices, and workplace rules. Yet little progress has been made in elaborating testable theory of such politics. Under what conditions does policy reform through litigation succeed? How much variation - across 
policy domains and court systems - in success rates exist, and what factors best explain that variation? Strikingly, there is no systematic research on a host of variables that one would think might be important, including differences in: national rules governing standing; discretion to send preliminary references to the $\mathrm{ECJ}$; local settlement regimes; provision of remedies; etc. No one has yet charted the growth of law firms specializing in litigating European law, or examined how such growth has impacted legal integration. Social scientists have given more attention to various 'extra-legal' factors, such as the relative capacities of potential litigants to organize themselves, differences in levels of resources that interest groups command, the openness of non-judicial state structures to process social demands, and the 'fit' between supranational and national modes of governance. But this research typically examines only a small number of national cases, in just one or two policy areas. We still desperately need comparative, contextually-rich case studies that blend the lawyer's concern with doctrinal evolution, and the social scientist's concern with explanation, in a sustained way.

\subsection{The Constitution and Judicial Modes of Governance}

The rhetoric of constitutionalization has been at the heart of discourse on legal integration for more than thirty years. The discourse implies that a constitution has been constructed out of a treaty. I find the various arguments associated with this rhetoric theoretically defensible, and empirically useful. In my view, it would be an artificial, tortuous, but not impossible exercise to define the term, 'constitution', so as to exclude the Rome Treaty, while including most constitutions of established nation states. My preference would be to start with a generic conception of the words, constitution and constitutionalism, and then to situate the EC's particular experience comparatively, relative to that of other polities. By constitution, I mean a body of meta-rules: normative statements that govern how all other rules are to be made, applied, and interpreted (Stone, 1994). Robust constitutionalism - the norm that the exercise of public authority must conform to constitutional norms or be invalid juridically - is rare in the world. Wherever constitutionalism presently exists, it has emerged through a combination of practice and design. The paradigmatic cases are all those that have been produced through the gradual consolidation of the power of judges to review the legality of the acts of legislatures and executives. The Community experienced this same process.

Ultimately, the EC experience - the 'Treaty-as-Constitution', the 'Constitution-as-Process' created the conditions for its own demise. Europe is presently experiencing a 'constitutional moment', the result of which is known: the Union will soon have a 'real' Constitution, properly signed and stamped in all of the right places. Scholars have already produced a small mountain of material analysing the constitution-making process, which I will not comment upon here. Instead, I will briefly address the relationship between European integration and constitutionalization, on the one hand, and the present proceedings on the other. 
First, it should be obvious that the move to produce a formal constitution cannot be dissociated from the overall process of integration. The so-called 'democratic deficit' and the various 'legitimacy gaps' that allegedly afflict the EC took on salience with the broad expansion of supranational governance. If EC programs had not become meaningful to the lives of more and more people, the democratic legitimacy of the European political system would have remained a rather distant question debated, if at all, by the same elites who have always dominated EC politics. The present reflects the legacy of the past in an even more profound way. It is clear that much of what the constitutional convention has done is to codify what had been institutionalized over the course of decades. ${ }^{25}$ As Lenaerts and Desomer (2002) showed, the "essential bricks" and mortar for a "constitutional treaty" of the EU had hardened over four decades, under the ECJ's tutelage. The most striking - and, to my mind, most important - examples are the codification of a charter of rights, and the consecration of proportionality as a general norm of government.

Second, one of the purest measures of the success of the Court's bid to constitutionalize the treaty system in the 1960s is the overloading of the preliminary reference procedure. In the 1980s, the Court was still able to process references in less than a year; today, the average delay from date of reference to date of decision is more than three years. The Commission's more aggressive use of enforcement actions has also increased the burden on the Court. In 1970, the ECJ rendered 64 rulings; it issued 132 in 1980, and 275 in 2000. The number of cases pending before the ECJ and the Court of First Instance rose from barely 200 in 1980 to more than 1,300 in 2000 . Given that the demand for more adjudication of EC law will only grow, the system is already in deep crisis. Reforms have been proposed, including: transforming the legal system into a hierarchically-organized appellate system, with the ECJ at its apex; creating lower level EU courts of referral - a kind of 'circuit court' system to help process references - which would refer to the ECJ the most important questions of law; and expanding the jurisdiction of the Court of First Instance to deal with disputes related to the interpretation of EC secondary legislation, especially in more technical areas of EC law.

Third, the European Court governs primarily through precedent, through propagating doctrinal frameworks that guide the argumentation and decision-making of lawyers, judges, and governmental officials. ${ }^{26} \mathrm{Had}$ the Court wavered in its commitment to building precedent, there would have been no constitutionalization of the Treaty, no steady judicialization of EC policymaking, no Europeanization of national law. Precedent, quite literally, embodies the past, and the past that matters in judicial politics is path dependent. At the same time, it is a potent instrument of organizing the future, normatively. The Court has been extraordinarily

25 There are, of course, important exceptions that have claimed a disproportionate share of attention (e.g. voting rights in the Council of Ministers).

26 The book, but not this paper, devotes a great deal of space to theorizing precedent and charting the evolution of practices associated with precedent in the EC. 
successful at inducing legal and political elites to reproduce the modes of reasoning it had applied, on a step-by-step basis in the past, to the problems of the present.

Last, without precedent, there is no proportionality. In my view, with the exception of the diffusion of the Court's constitutional doctrines (Stone Sweet, 2004), the most transformative institutional innovation in the history of legal integration will be the emergence of proportionality balancing as a master technique of judicial governance in the EU. ${ }^{27}$ For more than three decades now, the Court has consciously embraced, and sought to extend, proportionality standards. They now permeate virtually every domain of European law. In 1990, with the Treaty of European Union, the Member States ratified the Court's commitment to the principle. As revised, the Treaty of Rome now reads (Art. 5.3): "Any action by the Community shall not go beyond what is necessary to achieve the objectives of this Treaty". Further, as we have seen, the Court also requires all judges in the Union to deploy least-means tests to control the measures taken by the Member States in areas governed by EC law. The institutionalization of such control judicializes the European polity in a profound, and unusually formal, sense. If proportionality is to be at the core of European governance, then the judicial (re)construction of Europe has barely begun.

27 If direct effect and supremacy make up the necessary 'hardware' for the adjudication of EC law, proportionality appears to be evolving into its basic 'operating system'. 


\section{References}

\section{Rulings of the European Court of Justice}

Van Gend en Loos, ECJ 26/62 [1963] ECR 1.

Costa, ECJ 6/64 [1964] ECR 585.

Dassonville, ECJ 8/74 [1974] ECR 837.

Van Duyn, ECJ 41/74 [1974] ECR 1337.

Defrenne II, ECJ 43/75 [1976] ECR 455.

De Peijper. ECJ 104/75, [1976] ECR 613.

Kramer, ECJ 3/76 [1976] ECR 1279.

Simmenthal, ECJ 106/77 [1978] ECR 629.

Cassis de Dijon, ECJ 120/78 [1979] ECR 649.

Parti Écologiste "Les Vert" v. European Parliament, ECJ 294/83 [1986] ECR 1339.

Von Colson, ECJ 14/83 [1984] ECR 1891.

Marshall I, ECJ 152/84 [1986] ECR 723.

Marleasing, ECJ C-106/89 [1990] ECR I-4135.

Francovich, ECJ C-6 \& 9/90 [1991] ECR I-5357.

Dori, ECJ C-91/92 [1994] ECR I-3325.

Keck, ECJ C-267 and C-268/91 [1993] ECR I-6097.

Brasserie du Pecheur, ECJ C-46/93 [1996] ECR I-1029.

\section{General}

Alter, Karen (2001) Establishing the Supremacy of European Law. Oxford: Oxford University Press.

Alter, Karen and Sophie Meunier-Aitshalia (1994) 'Judicial Politics in the European Community: European Integration and the Pathbreaking Cassis de Dijon Decision', Comparative Political Studies 26: 535.

Anderson, Svein and Kjell Eliasson (1991) 'European Community Lobbying', European Journal of Political Research 20: 173. 
Berlin, Dominique (1992) 'Interactions between the Lawmaker and the Judiciary within the EC', Legal Issues of European Integration 92: 17.

Börzel, Tanja (2003) 'Guarding the Treaty: The Compliance Strategies of the European Commission', The State of the European Union: Law, Politics, and Society 6: 197.

Burley, Anne-Marie and Walter Mattli (1993) 'Europe Before the Court: A Political Theory of Legal Integration', International Organization 47: 41.

Cichowski, Rachel (2001) 'Judicial Rulemaking and the Institutionalization of EU Sex Equality Policy', in A. Stone Sweet, W. Sandholtz and N. Fligstein (eds.) The Institutionalization of Europe. Oxford: Oxford University Press.

Cichowski, Rachel (1998) 'Integrating the Environment: The European Court and the Construction of Supranational Policy', Journal of European Public Policy 5: 387.

Craig, Paul, and Grainne de Burca (1998) EU Law. Oxford: Oxford University Press.

Curtin, Deirdre (1993) 'The Constitutional Structure of the Union: A Europe of Bits and Pieces', Common Market Law Review 30: 17.

Curtin, Deirdre (1990) 'Scalping the Community Legislator: Occupational Pensions and "Barber"', Common Market Law Review 27: 475.

Dehousse, Renaud (1994) La Cour de Justice des Communautés Européennes. Paris: Montchrestien.

Dogan, Rhys (1997) 'Comitology: Little Processes with Big Implications', West European Politics 20: 31.

Eckstein, Harry (1988) 'A Culturalist Theory of Political Change', American Political Science Review 82: 789.

Egan, Michelle (2001) Constructing a European Market: Standards, Regulations, and Governance. Oxford: Oxford University Press.

Ellis, Evelyn (2000) 'The Recent Jurisprudence of the Court of Justice in the Field of Sex Equality', Common Market Law Review 27: 1403.

Ellis, Evelyn (1998) European Community Sex Equality Law. Oxford: Oxford University Press.

Empel, Martijn Van (1992) 'The 1992 Programme: Interaction Between Legislator And Judiciary', Legal Issues of European Integration 92: 1.

Farrell, Henry and Adrienne Héritier (2003) 'Formal and Informal Institutions Under Codecision: Continuous Constitution-Building in Europe', Governance 16: 577.

Fernandez Esteban, Maria Luisa (1994) 'La Noción de Constitución Europea en la Jurisprudencia del Tribunal de Justicia de las Comunidas Europeas', Revista Española de Derecho Constitucional 14: 241. 
Fligstein, Neil (2001) The Architecture of Markets: An Economic Sociology of Twenty-FirstCentury Capitalist Societies. Princeton: Princeton University Press.

Fligstein, Neil and Peter Brantley (1995) 'The Single Market Program and the Interests of Business', in B. Eichengreen and J. Frieden (eds.) Politics and Institutions in an Integrated Europe. Berlin: Springer Verlag.

Fligstein, Neil and Iona Mara Drita (1996) 'How to Make a Market: Reflections on the European Union's Single Market Program', American Journal of Sociology 102: 1.

Fligstein, Neil and Jason McNichol (1998) 'The Institutional Terrain of the European Union', in W. Sandholtz and A. Stone Sweet (eds.) European Integration and Supranational Governance. Oxford: Oxford University Press.

Fligstein, Neil and Alec Stone Sweet (2002) 'Of Polities and Markets: An Institutionalist Account of European Integration', American Journal of Sociology 107: 1206.

Garrett, Geoffrey (1995) 'The Politics of Legal Integration in the European Union', International Organization 49: 171.

Garrett, Geoffrey (1992) 'International Cooperation and Institutional Choice: The EC's Internal Market', International Organization 46: 533.

Goldstein, Leslie Friedman (2001) Constituting Federal Sovereignty: The European Union in Comparative Context. Baltimore: Johns Hopkins.

Greenwood, Justin and Mark Aspinwall (eds.) (1998) Collective Action in the European Union: Interests and the New Politics of Associability. London and New York: Routledge.

Haas, Ernst (1961) 'International Integration: The European and the Universal Process', International Organization 15: 366.

Haas, Ernst (1958) The Uniting of Europe: Political, Social, and Economic Forces, 1950-57. Stanford: Stanford University Press.

Hall, Peter and Rosemary Taylor (1996) 'Political Science and the Three Institutionalisms'. Political Studies 44: 936.

Harlow, Carol (1992) 'A Community of Interests? Making the Most of European Law', Modern Law Review 55: 331.

Hartley, Trevor (2001) 'The Constitutional Foundations of the European Union', The Law Quarterly Review 117: 225.

Huber, John and Charles Shipan (2000) 'The Costs of Control: Legislators, Agencies, and Transaction Costs', Legislative Studies Quarterly 25: 25.

Jarvis, Malcolm (1998) The Application of EC Law by National Courts. Oxford: Oxford University Press. 
Joerges, Christian and Jürgen Neyer (1997) 'From Intergovernmental Bargaining to Deliberative Political Processes: The Constitutionalisation of Comitology', European Law Journal 3: 272.

Jupille, Joseph (2004) Procedural Politics: Influence and Institutional Choice in the European Union. New York: Cambridge University Press.

Keohane, Robert and Stanley Hoffman (1991) 'Institutional change in Europe in the 1980s', in R. Keohane and S. Hoffman (eds.) The New European Community. Boulder: Westview Press.

Kilroy, Bernadette A. (1996) 'Member State Control or Judicial Independence? The Integrative Role of the European Court of Justice, 1958-1994', unpublished manuscript.

Lenaerts, Koen (1990)'Constitutionalism and the Many Faces of Federalism', American Journal of Comparative Law 38: 205.

Lenaerts, Koen and Marlies Desomer (2002) 'Brick for a Constitutional Treaty of the European Union', European Law Review 27: 377.

Maher, Imelda (1994) 'National Courts as European Community Courts', Legal Studies 14: 226.

Mancini, Federico G. (1991) 'The Making of a Constitution for Europe', in R. Keohane and S. Hoffman (eds.) The New European Community. Boulder: Westview Press.

Mattli, Walter (1999) The Logic of Regional Integration: Europe and Beyond. New York: Cambridge University Press.

Mattli, Walter and Anne-Marie Slaughter (1998) 'Revisiting the European Court of Justice', International Organization 52: 177.

Maurer, Andreas and Wolfgang Wessels (2003) 'The European Union Matters: Structuring Self-Made Offers and Demands', in W. Wessels, A. Maurer and J. Mittag (eds.) Fifteen into One? The European Union and Its Member States. Manchester: Manchester University Press.

Mazey, Sonia and Jeremy Richardson (2001) 'Institutionalizing Promiscuity: CommissionInterest Group Relations in the EU', in A. Stone Sweet, W. Sandholtz and N. Fligstein (eds.) The Institutionalization of Europe. Oxford: Oxford University Press.

Mazey, Sonia and Jeremy Richardson (eds.) (1993) Lobbying in the European Union. Oxford: Oxford University Press.

Majone, Giandomenico (2001) 'Two Logics of Delegation: Agency and Fiduciary Relations in EU Governance', European Union Politics 2: 103.

Milgrom, Paul and John Roberts (1992) Economics, Organization and Management. Englewood Cliffs: Prentice-Hall International. 
Moe, Terry (1990) 'Political Institutions: The Neglected Side of the Story', Journal of Law, Economics, and Organisation 6: 213.

Moe, Terry (1987) 'An Assessment of the Positive Theory of Congressional Dominance', Legislative Studies Quarterly 12: 475.

Moravscik, Andrew (1998) The Choice for Europe: Social Purpose and State Power from Messina to Maastricht. Ithaca: Cornell University Press.

Moravscik, Andrew (1993) 'Preferences and Power in the European Community: A Liberal Intergovernmentalist Approach', Journal of Common Market Studies 31: 473.

Moravscik, Andrew (1991) 'Negotiating the Single European Act: National interests and Conventional Statecraft in the European Community', International Organization 45: 19.

Mortelmans, Kamiel (1991) 'Article 30 of the EEC Treaty and Legislation Relating to Market Circumstances: Time to Consider a New Definition?', Common Market Law Review 28: 115.

North, Douglass R. (1990) Institutions, Institutional Change, and Economic Performance. Cambridge: Cambridge University Press.

Nyikos, Stacy (2000) The European Court of Justice and the National Courts: Strategic Interaction within the EU Judicial Process. Doctoral Dissertation, Department of Government and Foreign Affairs, University of Virginia.

Oliver, Peter (1996) Free Movement of Goods in the European Community. London: Sweet and Maxwell.

Page, Edward and Dionyssis Dimitrakopoulos (1997) 'The Dynamics of EU Growth: A CrossTime Analysis', Journal of Theoretical Politics 3: 365.

Pierson, Paul (1998) 'The Path to European Integration: A Historical-Institutionalist Analysis', in W. Sandholtz and A. Stone Sweet (eds.) European Integration and Supranational Governance. Oxford: Oxford University Press.

Pitarkis, Jean-Yves and George Tridimas (2003) 'Joint Dynamics of Legal and Economic Integration in the European Union', European Journal of Law and Economics 16: 357.

Poiares Maduro, Miguel (1998) We, the Court: The European Court of Justice and the European Economic Constitution. Oxford: Hart Press.

Pollack, Mark (1997) 'Representing Diffuse Interests in EC Policy-Making', Journal of European Public Policy 4: 572.

Sandholtz, Wayne and Alec Stone Sweet (eds.) (1998) European Integration and Supranational Governance. Oxford: Oxford University Press.

Sandholtz, Wayne and John Zysman (1989) '1992: Recasting the European Bargain', World Politics 42: 95. 
Scharpf, Fritz W. (1996) 'Negative and Positive Integration in the Political Economy of European Welfare States', in G. Marks, F. Scharpf, P. Schmitter and W. Streeck (eds.) Governance in the European Union. Thousand Oaks: Sage Publications.

Schilling, Theodor (1996) 'The Autonomy of the Community Legal Order: An Analysis of Possible Foundations', Harvard Law Review 37: 389.

Schmitter, Phillippe and Wolfgang Streeck (1991) 'From National Corporatism to Transnational Pluralism', Politics and Society 19: 133.

Shapiro, Martin (1992) 'The European Court of Justice', in A. Sbragia (ed.) Euro-Politics. Washington, DC: Brookings Institution.

Shapiro, Martin and Alec Stone Sweet (2002) On Law, Politics, and Judicialization. Oxford: Oxford University Press.

Shapiro, Martin (1999) 'The European Court of Justice', in P. Craig and G. de Burca (eds.) The Evolution of EU Law. Oxford: Oxford University Press.

Slaughter, Anne-Marie, Alec Stone Sweet and Joseph H. H. Weiler (eds.) (1998) The European Court and the National Courts - Doctrine and Jurisprudence: Legal Change in its Social Context. Oxford and Evanston: Hart Press and Northwestern University Press.

Snyder, Francis (1996) 'The Effectiveness of European Law', Modern Law Review 56: 19.

Stein, Eric (1981) 'Lawyers, Judges, and the Making of a Transnational Constitution', American Journal of International Law 75: 1.

Steiner, Josephine (1992) 'Drawing the Line: Uses and Abuses of Article $30 \mathrm{EEC}$ ', Common Market Law Review 29: 749.

Stone, Alec (1994) 'What is a Supranational Constitution? An Essay in International Relations Theory', Review of Politics 56: 441.

Stone Sweet, Alec (2004) The Judicial Construction of Europe. Oxford: Oxford University Press.

Stone Sweet, Alec (2002) 'Constitutional Courts and Parliamentary Democracy', West European Politics 25: 77.

Stone Sweet, Alec (2000) Governing with Judges: Constitutional Politics in Europe. Oxford: Oxford University Press.

Stone Sweet, Alec (1999) 'Judicialization and the Construction of Governance', Comparative Political Studies 32: 147.

Stone Sweet, Alec (1998) Constitutional Dialogues in the European Community, in A-M. Slaughter, A. Stone Sweet and J. Weiler (eds.) The European Court and the National Courts: Legal Change in its Social, Political, and Economic Context. Oxford: Hart Press. 
Stone Sweet, Alec and Thomas Brunell (2001) 'The European Court, National Judges and Legal Integration: A Researcher's Guide to the Data Base on Preliminary References in European Law, 1958-98', European Law Journal 6: 117.

Stone Sweet, Alec and Thomas Brunell (1998a) 'Constructing a Supranational Constitution: Dispute Resolution and Governance in the European Community', American Political Science Review 92: 63.

Stone Sweet, Alec and Thomas Brunell (1998b) 'The European Court and the National Courts: A Statistical Analysis of Preliminary References, 1961-95', Journal of European Public Policy 5: 66.

Stone Sweet, Alec and James Caporaso (1998a) 'La Cour européenne et l'intégration', Revue Française de Science Politique 48: 195.

Stone Sweet, Alec and Margaret McCown (2003) 'Discretion and Precedent in European Law', in O. Wiklund (ed.) Judicial Discretion in European Perspective. Stockholm: Kluwer Law International.

Stone Sweet, Alec and Wayne Sandholtz (2002) 'Response to George Tsebelis and Geoffrey Garrett', Online at http://www.nuff.ox.ac.uk/Users/Sweet/index.html.

Stone Sweet, Alec and Wayne Sandholtz (1999) 'European Integration and Supranational Governance Revisted: Rejoinder to Branch and Øhrgaard', Journal of European Public Policy 6: 144.

Stone Sweet, Alec and Wayne Sandholtz (1997) 'European Integration and Supranational Governance', Journal of European Public Policy 4: 297.

Stone Sweet, Alec, Wayne Sandholtz and Neil Fligstein (2001) 'The Institutionalization of European Space', in A. Stone Sweet, W. Sandholtz and N. Fligstein (eds.) The Institutionalization of Europe. Oxford: Oxford University Press.

Stone Sweet, Alec, Wayne Sandholtz and Neil Fligstein (eds.) (2001) The Institutionalization of Europe. Oxford: Oxford University Press.

Thatcher, Mark and Alec Stone Sweet (eds.) (2002) 'Theory and Practice of Delegation to Non-Majoritarian Institutions', West European Politics, 25.

Timmermans, Christian (2003) 'The Constitutionalization of the European Union', Yearbook of European Law 22: 1.

Tridimas, Takis (1994) 'Horizontal Direct Effect of Directives: A Missed Opportunity?', European Law Review 19: 620.

Tsebelis, George and Geoffrey Garrett (2001) 'The Institutional Foundations of Intergovernmentalism and Supranationalism in the European Union', International Organization 55: 357.

Waltz, Kenneth (1979) Theory of International Politics. New York: McGraw-Hill. 
Ward, Angela (2000) Judicial Review and the Rights of Private Parties in EC Law. Oxford: Oxford University Press.

Weatherhill, Stephen (2003) Cases and Materials on EU Law. Oxford: Oxford University Press.

Weiler, Joseph H. H. (1999) 'The Constitution of the Common Marketplace: Text and Context in the Evolution of the Free Movement of Goods', in P. Craig and G. De Burca (eds.) The Evolution of EU Law. Oxford: Oxford University Press.

Weiler, Joseph H.H. (1994) 'A Quiet Revolution: The European Court and Its Interlocutors', Comparative Political Studies 26: 510.

Weiler, Joseph H.H. (1991) 'The Transformation of Europe', Yale Law Journal 100: 2403.

White, Eric L. (1989) 'In Search of the Limits to Article 30 of the EEC Treaty', Common Market Law Review 26: 235.

Witte, Bruno de (1998) 'The Pillar Structure and the Nature of the EU: Greek Temple or French Gothic Cathedral?', in T. Heukels, N. Blokker and M. Brus (eds.) The European Union after Amsterdam. Leiden: Europa Institute of Leiden University. 

Author: Alec Stone Sweet

Title: European Integration and the Legal System

Reihe Politikwissenschaft / Political Science Series 101

Editor: Sylvia Kritzinger

Associate Editor: Elisabet Torggler

ISSN: 1605-8003

(C) 2005 by the Department of Political Science, Institute for Advanced Studies (IHS),

Stumpergasse 56, A-1060 Vienna • 용 +43 1 59991-0 • Fax +43 1 59991-555 • http://www.ihs.ac.at 
ISSN: 1605-8003 